Essay

\title{
Conserving the Paraguay-Paraná Fluvial Corridor in the XXI Century: Conflicts, Threats, and Challenges
}

\author{
Claudio Rafael Mariano Baigún *(D) and Priscilla Gail Minotti
}

IIIA-CONICET, Instituto de Investigación e Ingeniería Ambiental, Universidad Nacional de San Martín, Provincia de Buenos Aires 1650, Argentina; pminotti@unsam.edu.ar

* Correspondence: cbaigun@gmail.com

Citation: Baigún, C.R.M.; Minotti, P.G. Conserving the Paraguay-Paraná Fluvial Corridor in the XXI Century: Conflicts, Threats, and Challenges. Sustainability 2021, 13, 5198.

https://doi.org/10.3390/su13095198

Academic Editor: Denielle M. Perry and Ian Harrison

Received: 1 February 2021

Accepted: 18 April 2021

Published: 6 May 2021

Publisher's Note: MDPI stays neutral with regard to jurisdictional claims in published maps and institutional affiliations.

Copyright: (c) 2021 by the authors. Licensee MDPI, Basel, Switzerland. This article is an open access article distributed under the terms and conditions of the Creative Commons Attribution (CC BY) license (https:// creativecommons.org/licenses/by/ $4.0 /)$.

\begin{abstract}
The Paraguay-Paraná river system represents a unique, free-flowing corridor that extends about $3500 \mathrm{~km}$ southwards from the Pantanal to the Rio de la Plata estuary, crossing four countries. The absence of fragmentation along the main channels and its still well-connected floodplains have preserved longitudinal and lateral functional and structural connectivity, defining critical ecological gradients for the biota and species life cycles. The lack of dams represents a noticeable feature that benefits migratory species supporting small-scale fisheries providing food security and the conservation of other ecosystem services with associated livelihoods. The ecological integrity of this corridor could be severely affected by the potential expansion of the Hidrovía Paraguay-Paraná for improving commercial trade, the foreseen installation of new dams in the Paraná basin, in addition to other current impacts and threats. Conservation of the corridor for societal benefits, involving the sustainable development of activities associated with the use of the fluvial territory, requires maintaining the natural ecological process that sustains livelihoods and biodiversity. This calls for innovative strategies encompassing water governance process, social and environmental information related to expected impacts, a better understanding of synergies between processes, and foremost an interdisciplinary approach to design and apply integrative and multi-scale management policies.
\end{abstract}

Keywords: Paraguay-Paraná fluvial corridor; Pantanal; Paraná Delta; structural and functional connectivity; Hidrovía Paraguay-Paraná; dams; connectivity; environmental flow; migratory fish

\section{Introduction}

Rivers are complex and multiscale systems where hydrologic connectivity plays a critical role in biophysical, ecological, and biochemical processes [1-3]. Free-flowing rivers are fluvial systems that flow undisturbed from source to mouth without encountering any dams, weirs, or barrages, and without being hemmed by dikes or levees [4]. These unfragmented river corridors are natural regional-scale features with extensive tracts of untransformed habitat, aligned along major environmental gradients [5].

Free-flowing rivers allow longitudinal, lateral, and vertical exchanges and transference of organic and inorganic matter, and organisms within and between phases of the hydrologic cycle [6-9]. In this context, connectivity represents the main pillar to maintain the structural and functional characteristics of fluvial systems and is considered the key factor controlling habitat heterogeneity and biotic diversity [10].

Fluvial connectivity encompasses both structural and functional components. The structural view describes how the different distribution of landscape units and physical characteristics of the catchment are spatial linked. The functional aspect addresses how fluxes of water, sediments, nutrients, and organisms circulate, are imported to and are exported from the system [11]. Therefore, functional connectivity represents the key attribute that connects and relates structural units along the hydrosystem [12]. Not surprisingly, connectivity has been incorporated as the central element of many conceptual models that attempt to explain patterns of functional and structural fluvial biocomplexity across spatial 
and temporal scales in river networks. These include the river continuum concept [13], the serial discontinuity concept [14], the flood pulse concept [15,16], the riverscape concept [17], the natural flow paradigm [18,19], the fluvial hydrosystem concept [20], the river ecosystem synthesis [21], the river machine concept [22], and the homogenizing force of flood pulse model [23].

The maintenance of fluvial connectivity should be underscored in water resource management. Unfragmented river corridors are natural regional-scale features with extensive tracts of untransformed habitat, aligned along major environmental gradients [5]. These fluvial corridors play a critical role in conservation and restoration processes by allowing the free flux of sediments, organisms, and nutrients [24]. As mentioned above, functional fluvial corridors need to meet several eco-hydrological requirements given by the recurrence of flood pulses and the free multidimensional connectivity [25]. In large rivers, connectivity also operates at different geographic scales and temporal dimensions [26-28], from small watersheds to regional catchment scales [29-31].

Connectivity in large rivers can be strongly affected by fragmentation due to dams, becoming a growing issue of the ecological integrity in transboundary basins, particularly those inhabited by migratory species [32]. Worldwide, dams have fragmented more than $60 \%$ of all large rivers (rivers $>1000 \mathrm{~km}$ in length) [4]. More than 45,000 dams above $15 \mathrm{~m}$ high have been constructed representing about $15 \%$ of the total annual river runoff globally, and only 35\% of the world's large basins (102 systems) remain completely unfragmented [33-35]. Aggressive plans to continue developing dams in the large basins of South America, such as the Amazon, are being pushed forward with a scenario of increasing fragmentation [36-38]. In De La Plata Basin, the Upper Paraná River and its main tributaries have been transformed into chains of reservoirs [39,40].

A different panorama presents the Paraguay-Paraná fluvial corridor (hereinafter referred to as the Corridor), which remains unfragmented by dams. In-depth reviews of some of these aspects have been devoted to the Pantanal [41-43] and the Paraná Delta region [44]. For the Upper Paraguay River, the general hydrological characteristics are presented by [45], together with its fisheries, pollution sources, and the threats related to dam construction. In turn, a synthesis provided by [46] provided an overall view of the Corridor in Argentina. All these studies had a regional scope but did not address an ecological corridor perspective, and issues related to conservation conflicts that have been largely ignored. Moreover, trends in the development of hydro-infrastructure together with institutional, economic, and social conflicts, have merged in the last decades as critical drivers that could influence this conservation status. This scenario raises interesting and complex questions on the reasons behind this situation, wondering if the current status of the Corridor could be maintained in the future.

Our study seeks to provide an updated review of the most salient features of the Paraguay-Paraná Corridor, presenting its current environmental, socio-economic, and legal characteristics which affect the maintenance of its ecological functioning, putting the emphasis on fisheries as the most critical and visible biodiversity-ecosystem service. We discuss ongoing and future threats that can put at risk the ecological integrity of the Paraguay-Paraná Corridor, particularly those related to the Hidrovía waterway, and describe some challenges and approaches that may help to maintain its non-fragmented character and the durability of this conservation status.

\section{The Paraguay-Paraná Fluvial Corridor}

The Paraguay-Paraná fluvial corridor forms one of the main fluvial axes of the La Plata River basin crossing from the tropical Paraguay ecoregion to the temperate Lower Paraná [47] (Figure 1). It includes an extended belt of free-connected floodplains and major wetlands such as the iconic Pantanal, located in the upper part of the corridor. The Corridor represents a rare case of a transboundary system that has not yet been fragmented by dams, which still retains its regular flood pulses and free connectivity between the main channel and its vast floodplains. This system also exhibits a distinctive ecological and 
biogeographical role by connecting different landscapes [48] and is considered a complex mosaic of wetlands [49].

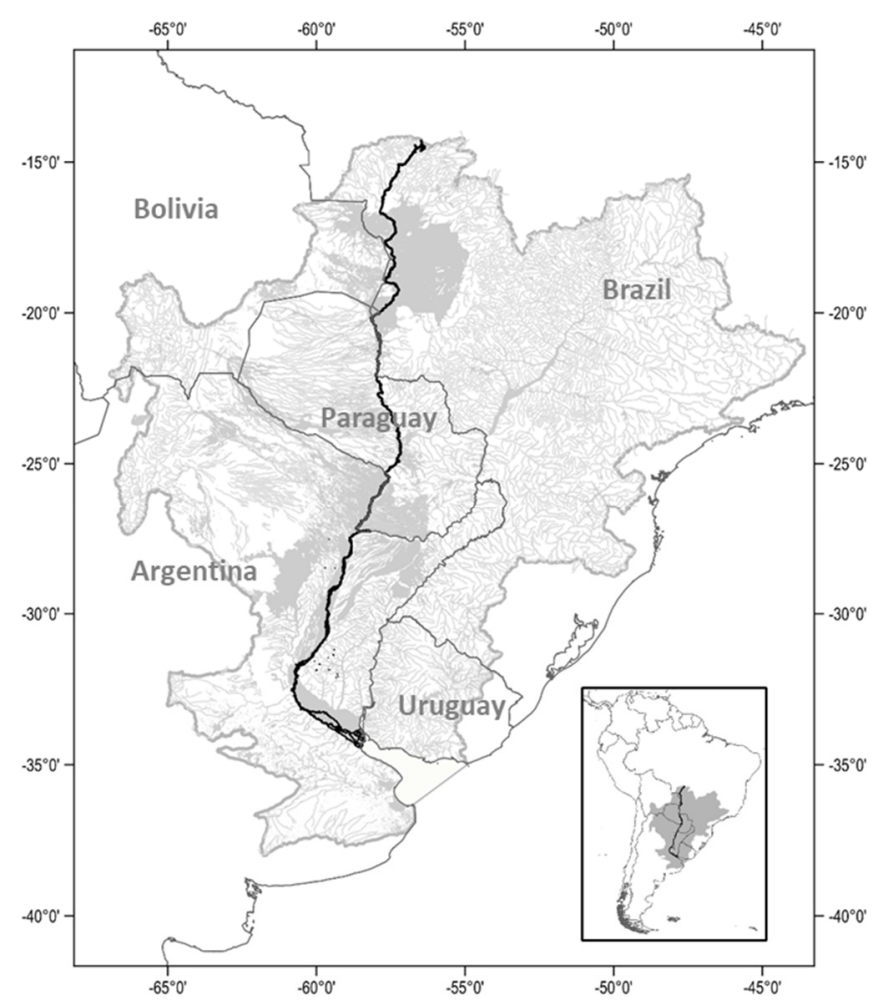

(a)

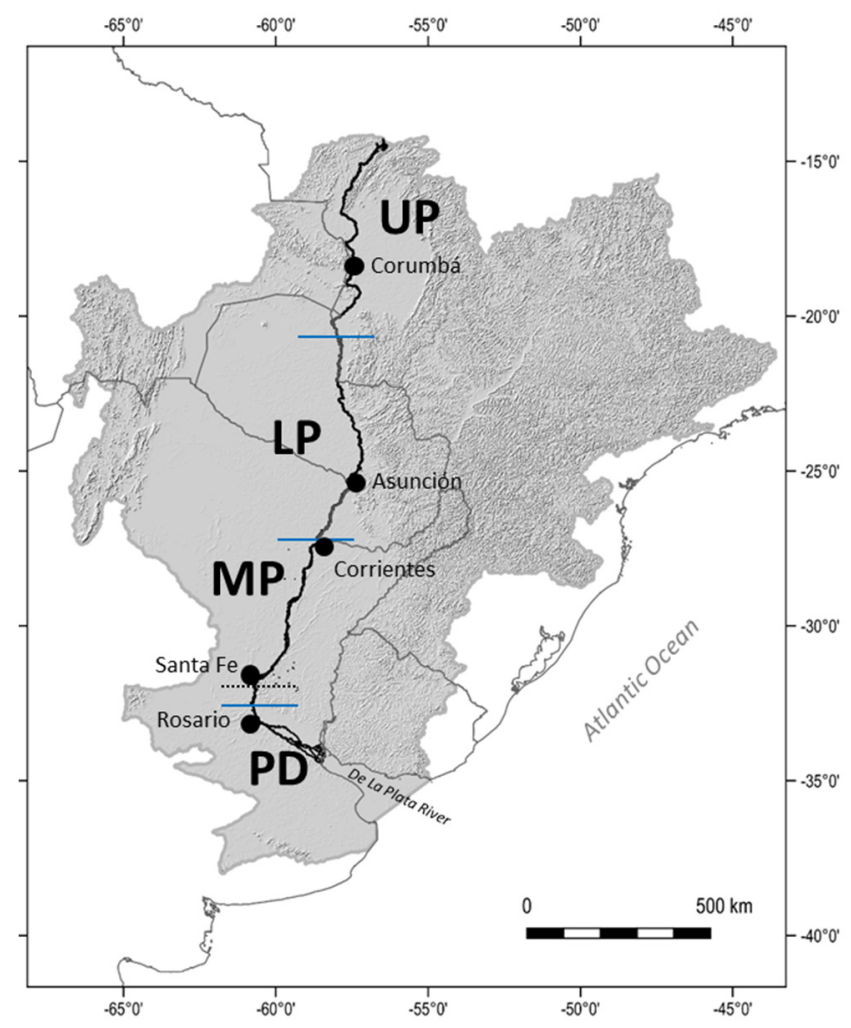

(b)

Figure 1. The Paraguay-Paraná Fluvial Corridor. (a) De La Plata Basin with the main drainage network and large wetland areas in light grey and the Paraguay-Paraná fluvial axis in black; (b) Main cities mentioned in the text, and sections of the Paraguay-Paraná Fluvial Corridor (within blue lines); UP: Upper Paraguay; LP: Lower Paraguay; MP: Middle Paraná; PD: Paraná Delta; the dotted line indicates the upper limit of the contracted out Hidrovía waterway that runs from Santa Fe city (Argentina) to the Ocean.

\subsection{Main Environmental Characteristics}

The Paraguay-Paraná corridor represents a fluvial axis formed by the Paraguay River and the channels of the middle and lower reaches of the Paraná River ending at the Rio de la Plata estuary (Figure 1). It covers a latitudinal range between $20^{\circ}$ and $35^{\circ} \mathrm{S}$, crossing four countries: Brazil, Bolivia, Paraguay, and Argentina. The Corridor has a length of $3400 \mathrm{~km}$, ranking 4th among the largest unfragmented river systems [4]. It represents the endpoint of lateral free-flowing large tributary rivers such as the Bermejo, Pilcomayo, Apa, Taquari, Negro, and Miranda (Figure 1a). The Corridor can be divided into four distinctive sections, two located on the Paraguay River and the other two on the Paraná (Figure 1b). This division takes into account the general hydrological, geomorphological, and land use differences between them. The fluvial landscape changes along the Corridor, the most remarkable being the change in width of the main river channel (Figure 2).

The first section (UP) comprises the Upper Paraguay and the Pantanal, an extensive wetland region of 147,500 $\mathrm{km}^{2}$ distributed in Brazil (78\%), Bolivia (18\%) and Paraguay (4\%). In Brazil, the Pantanal is surrounded by a plateau, the Planalto region, with elevations around $800 \mathrm{~m}[50,51]$. The Planalto represents the headwater region, with steep slope areas and a low relief plain of temporal or permanent shallow lake wetlands [52]. The Pantanal exhibits a noticeable seasonal annual flood regime [53]. The high water level determines the extent of terrestrial and aquatic habitats, enables the migration of fish and other aquatic species, and influences biogeochemical cycling on the Pantanal's floodplains [43]. The rainy season takes place mostly from late southern spring to summer (November-March), water 
supplied by local rainfall and inflows from Planalto rivers [54]. The dry period takes place from April to September, characterized by intense evapotranspiration, with biota well adapted to such huge variability [55].

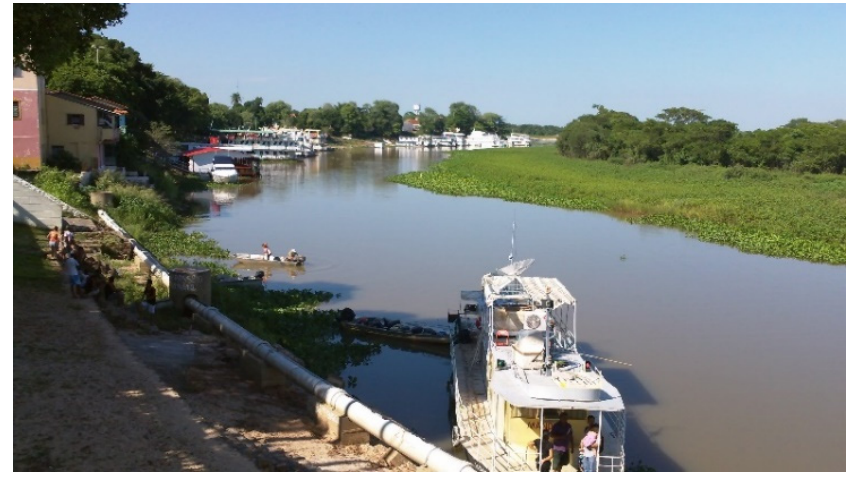

(a)

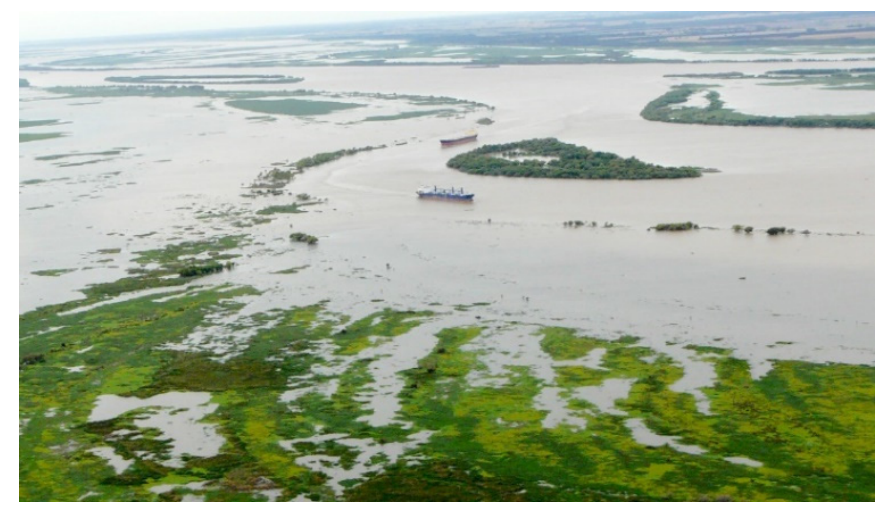

(b)

Figure 2. The landscape of the Corridor's main river channels. a. Paraguay River at Puerto Cáceres, Upper Paraguay and Pantanal section. B. Paraná River near Ramallo city, Lower Paraná Delta region. Photo credits: (a). C. Baigun; (b). P. Minotti.

The second section (LP) comprises the Paraguay River that acts as the outlet of the Pantanal and ends at the confluence with the Paraná River. Temporal and permanent anabranches occupy almost $50 \%$ of the alluvial valley, full of scroll-bars and connecting semicircular shallow ponds. Floods in rivers flowing through the Pantanal are dampened and delayed; thus, flow peaks in this second sector downstream of Pantanal are delayed by 3-4 months [56]. Near the end of this reach, of noticeable importance is the entrance of the Bermejo River, which carries during its wet season heavy loads of sediments that originated in Andean headwaters during the rainfall season [57].

The third section (MP) starts near Corrientes city in Argentina, at the junction between the Paraguay and Paraná rivers, and runs to the apex of the Paraná Delta near Diamante city, comprising part of the area locally known as Middle Paraná. At the confluence, the mean annual discharge of the Paraná River only rises from 11,983 to $16,941 \mathrm{~m}^{3} / \mathrm{s}$, while the suspended sediment discharge increases from 5. to 106 million tons per year [58], of which $28 \%$ are clay $(28 \%), 56 \%$ silt, and $16 \%$ sand [59]. This section is characterized by one or more anabranches having unstable sand bars and islands, with an extensive fringing floodplain ranging from 13 to $60 \mathrm{~km}$ in width [60]. It shows the complex spatial geometry typical of undisturbed floodplain rivers, with a meandering thalweg in its main channel $[61,62]$. The surrounding floodplain of this sector of the Paraná reaches an area of $19,240 \mathrm{~km}^{2}$ [63].

The fourth section of the Corridor (PD) is comprised by the Delta region -also known as the Lower Paraná, which forms a fluvial-coastal complex of circa $17,500 \mathrm{~km}^{2}$ with multimodal and unpredictable flood pulses of different sources, including the Paraná and Uruguay rivers, upland tributaries, local rainfall, ocean tides and storm surges coming from De La Plata Estuary [64,65].

\subsection{Structural and Functional Connectivity}

The Corridor exhibits a diverse mosaic of wetlands with ecological conditions that vary according to relative elevation, distance to the main river channel, and fluvial connectivity $[48,66]$. Different approaches have been used to recognize this spatial heterogeneity. In the Pantanal, the main focus was given to wetland habitat types, considering the predictability and seasonality of floods, together with the vegetation physiognomy and its local names [67]. In turn, Refs. [10,68] following the fluvial hydrosystem concept identified functional nested habitats in the middle and lower Paraguay River floodplain. For the Argentine sections, the functional and structural complexity of the Corridor was delineated by [49] based on drainage patterns and wetland landscape configuration. This approach 
recognized several distinct wetland landscape systems that can be contextualized as territories having a common geological, climatic, and geomorphological origin, where the action of water from precipitation, surface runoff, and groundwater movement, has generated distinctive drainage and water permanence patterns. Spatial structural differences at a broader scale, known as wetland regions, have been also defined by [69] for the De La Plata Basin, which includes the Corridor.

The natural alternance of potamophase and limnophase under free connectivity conditions triggers several key ecological processes. Floods and high water stages allow the connection of isolated floodplain lakes to the main river or anabranches through a diverse network of secondary channels, with mobilization of nutrients, sediments, seeds, eggs, larvae, etc. [70]. The start of the limnophase promotes the isolation of floodplain lakes and the recruitment of organisms to the main channel, as well as the exportation of organic matter and nutrients [71]. Low-water periods increase the dissimilarity between benthos of the floodplain lakes and enhance the influence of local driving forces [72-75]. These differences have also been noted between main and secondary channels [76]. Such opposite effects maintain the generation of ecological gradients that influence the biotic composition and limnological characteristics of the floodplain, highlighting the importance of preserving the alternation of floods and droughts in the corridor as relevant ecological processes.

The interaction between hydrological variations and floodplain connectivity has a strong influence on fish movements and assemblage composition. Fish dispersion between floodplain habitats and channel networks is regulated by fluvial connectivity [77,78]. In turn, the high waters stage is associated with fish species movements between lotic and lentic habitats, increasing species turnover and prompting more diversified assemblages as the flooding process takes place in the alluvial valley $[79,80]$. Fish assemblages can also differ spatially across the floodplain landscape considering the distance from the floodplain lakes to the main channel [81]. Increasing connectivity enables large areas in the floodplain to become invaded by fish larvae and juveniles entering from the main channel, so they have access to refuge habitats, food supply, or better-growing conditions when they reach the floodplain lakes [82-85]. In this sense, the small, shallow, and densely vegetated lakes spread across the floodplains play a critical role in juveniles stages for both sedentary and migratory species [86-90]. In turn, the main channel habitat is characterized by migratory fish with complex migratory movements. In the Pantanal there are 23 species recognized as long-distance migratory fish $(>100 \mathrm{~km})$, most of them are the target of commercial and recreational fisheries [91,92]. For the Lower Paraná, [93] identified 40 migratory species that perform trophic, thermal, and reproductive migrations of varying lengths, both upstream and downstream, governed by hydrological and climatic stimuli [94]. For example, the life cycle of sábalo (Prochilodus lineatus), the main commercial species in the Middle and Lower Paraná, is closely associated with the flow regime and floodplain stage in the early stages of its life cycle [93,94] (Figure 3). After free spawning in the main channels, eggs and larvae drift entering into the floodplain, where they grow with better food and refuge habitats [95].

\subsection{Ecosystem Services}

The Corridor includes several socio-ecological systems distributed along its entire length, supporting a large variety of ecosystem services whose importance varies depending on the section. In the Pantanal, these services sustain economic activities both in the Planalto area (agriculture, agroindustries, and urban areas) as well as in the floodplains (extensive grazing by livestock on native pastures, fishing, tourism, and food security for communities and traditional people) [96,97]. The cultural traditions of the people living in the Pantanal ("Pantaneiros") are shaped by the flood pulse regime [98]. Cattle ranching is of particular importance in the Pantanal area, being one of the major sources of income [99]. Estimations of ecosystem services values in the Pantanal ranged from $6000 \mathrm{USD} / \mathrm{ha}$ /year to 10,000 USD/ha/year, considering ecosystem services related to water supply, disturbance regulation, waste treatment, cultural value, water regulation, nutrient cycling, recreation, 
and habitat value $[100,101]$. On the other hand, in the Paraná Delta, detailed studies have been performed to recognize an array of ecosystem services provided by wetlands [102,103]. Identified services have been associated with water supply for production and consumption, flood buffering capacity, improving water quality, provision of habitat for species of socio-economic interest, biodiversity (including endangered, migratory, and endemic species), provision of scenic environments for recreation and tourism, carbon storage, and several activities such as fishing, honey production, forestry, and cattle ranching [104]. The value of ecosystem goods and services for the Paraná Delta wetlands was estimated between 1169 USD and 1277 USD/ha/year [105].

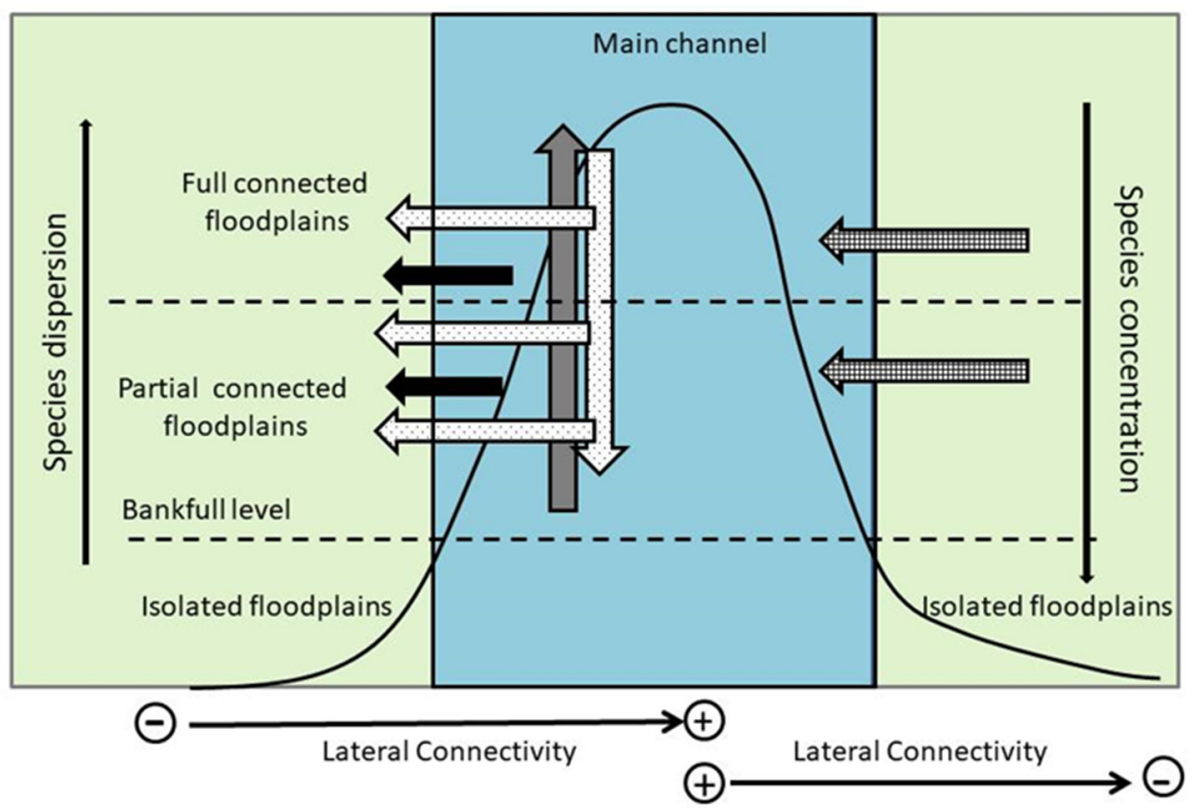

Figure 3. Life history patterns related to reproductive traits of Prochilodus lineatus in the Corridor, associated with the flow regime and floodplain connectivity; black curve: hydrological regime; filled grey arrows: adult migration during flow increase for spawning purposes; dotted arrows: downstream and lateral larvae drift during high flow; gridded arrows: recruitment of juveniles; black arrows: trophic movements of adults.

Artisanal fisheries represent probably the most important ecosystem service along the corridor overall. Like most small-scale fisheries elsewhere, they provide livelihoods for rural communities, contribute to alleviating poverty, provide food security, employment for local and indigenous people based on open access resources and represent an engine for local and regional economies [106-108]. Fisheries in the Pantanal provide important resources which support subsistence and generate both direct and indirect economic benefits to local people [109]. In the last decade, there has been increasing pressure on fisheries in the Pantanal, under the assumption that they promoted the depletion of fish species and target species abundance [110]. The reduction in the touristic fisheries activity has prompted new regulations oriented to ban some specific gears and limit the catch quota for the artisanal fishery [111]. In towns distributed along the corridor, fishers have often other sources of income, but in distant and more remote areas, fishing represents the main source of income for a great number of households [112]. In the Middle and Lower Paraná, artisanal fisheries play a dominant economic role as most of the harvest is sold to middlemen, freezing plants, or in informal markets [113]. Of particular interest are long-range migratory species such as sábalo (Prochilodus lineatus), surubí (Pseudoplatystoma corruscans, P. reticulatus), boga (Megaleporinus obtusidens), pacú (Piaractus mesopotamicus), and dorado (Salminus brasiliensis), that support artisanal, recreational, and subsistence fisheries, as observed in other large neotropical rivers [114]. 
All the countries of the Corridor allow free access to fishing and there are no territorial users rights fisheries (TURF) that limit the communities' fishing. For the numerous fisheries distributed along the corridor, management problems are almost similar, i.e., legislations lack participatory management, have poor governance mechanisms, present problems with fishing rights tenure. There is a lack of policy enforcement, controls are almost absent, fisheries management agencies are generally weak and with limited resources, and it is difficult to monitor fishery trends as appropriate statistics are not available. Loss of fishing territories to private ports and marinas is also common in urban areas.

\section{The Hidrovía Paraguay-Paraná}

The Corridor is probably best globally recognized for the presence of a waterway known as the Hidrovía Paraná-Paraguay (Hidrovía). The concept of the Paraná and Paraguay rivers as a waterway has promoted the vision of economic integration of the La Plata Basin including Argentina, Bolivia, Brazil, Paraguay, and Uruguay, through improved trade and navigation [115]. The Hidrovía has also been envisioned as part of a large system of waterway networks connecting the De La Plata, Orinoco, and Amazon basins to promote the social and economic integration of the South American continent [116].

Currently, the Hidrovía has two very different operational sections (Figure 1b). Upstream from Santa Fe City, the Corridor navigation takes place under natural conditions, which only allow the transit of regular barges, particularly in the Paraguay River. The depth between Corumba to Puerto Caceres is only 6 feet, from Corumba to Asuncion is 10 feet, and from the Paraguay-Paraná confluence to Santa Fe City is 13 feet. These sections have narrow and winding channels, with several passages between or with rocky outcrops, making navigation more difficult for larger vessels and convoys. South of Santa Fe city, the waterway dredging, operation and maintenance is contracted since 1995. The navigation channel is $100 \mathrm{~m}$ wide representing only $5 \%$ of the natural width of the main river, which sometimes exceeds $2 \mathrm{~km}$. The depth is 28 feet from Santa Fe to Rosario and 34 feet from Rosario to the Rio de la Plata, which allow navigation by ocean-going vessels.

Existing dredging activity is not constant in every pass because the Corridor presents navigation limitations in some passes only during the dry season, particularly in the lower Paraguay River, where several rocky outcrops make shipping traffic difficult. There are a total of 190 such passes in the river corridor, ranging from 1 to $3 \mathrm{~km}$ in length, representing approximately $380 \mathrm{~km}$ or $11 \%$ of the corridor length. In the Pantanal region, $21 \mathrm{critical}$ passes have been identified [117].

The heavy fluvial traffic of the Hidrovía has motivated demands from the shipping and commodity sectors to widen the width of the channel, to permit overtaking and/or crossing of vessels, avoiding delays and higher operating costs. Strong lobbying from the agricultural sector has resurrected the extension of the Hidrova to the Pantanal. This would enable the large-scale shipping of soybeans, one of the principal products of the state of Mato Grosso [118,119].

The first studies of the Hidrovía waterway feasibility focused on the economic and technical aspects to evaluate the capacity of the Corridor to reduce transport costs [120-124], and on operational issues associated with infrastructure, safety, regulations, and standards [125]. One of the main criticisms of such feasibility studies was the lack of consideration given to environmental costs [126-131]. At the same time, such studies were questioned for the use of inappropriate engineering models that did not take into account the complex and highly variable interactions between surface and groundwater, or between the main channel and the floodplains, including effects on the flora and fauna of the Pantanal [132]. Recently, [133] presented a short review of potential impacts of the current and projected Hidrovía waterway on the Paraguay-Paraná wetland systems, pointing out that many knowledge gaps and uncertainties remain.

Hidrovía and its expected expansion is by far the most conflictive issue associated with the Corridor conservation. Despite being a project already initiated in the lower part of the Paraná River, it has not yet obtained fully social approval and environmental 
consensus to be extended toward the Pantanal. As a major infrastructure project, it has received a balanced number of stakeholders that support or reject the project (Figure 4). The development and government sectors include actors with moderate to a high degree of support and influence, while the sector that rejects the project appears to have a more diverse influence capacity and probably more social consensus. The reasons for rejection are complex and rooted in social, economic, environmental, institutional, and political aspects, which differ greatly from one country to another in the basin $[119,134,135]$. Stakeholders exhibit different degrees of support and influence at a regional scale, explaining why a call to expand the waterway is still under debate and could be limited to more regional initiatives instead to be transformed into a large-scale transboundary project.

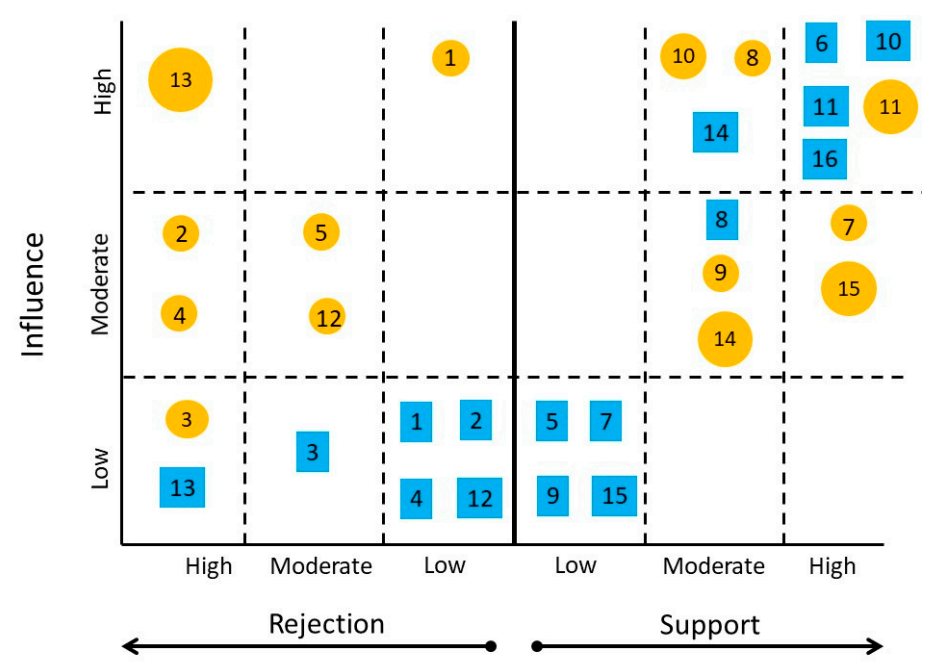

Figure 4. Main stakeholders/sectors that support and reject the Hidrovía project. The circled numbers correspond to the Lower and Upper Paraguay sectors, whereas the squared numbers represent the Middle and Delta sectors. 1: Tourism; 2: Indigenous organizations; 3: Artisanal fishing; 4: Recreational fishing; 5: Municipal governments; 6: Argentinean government; 7: Paraguayan government; 8: Brazilian government; 9: Bolivian government; 10: Agribusiness sector; 11: Shipping and dredging sector; 12: Academic sector; 13: NGO's sector; 14: International finance sector; 15: Mining sector; 16: Industrial sector.

\section{Anthropic Factors That Affect the Conservation of the Corridor}

Despite its unfragmented condition, the corridor is not free from anthropic interventions. Landscape modifications are related to shore urbanizations along the corridor, small dam development in the Pantanal [136-138], and ditches and diking in the Paraná Delta [44]. Other interventions relate directly to the different uses of the main channel. Climate variability in synergy with these land and water uses can multiply conservation threats and impacts. In this context, we identify and shortly describe the main issues related to anthropic interventions on natural resources and the riverscape along the corridor. In some cases, impacts can be related to different processes located in the hinterlands, which also have a direct influence on the ecological integrity of the corridor.

\subsection{Infrastructure}

\subsubsection{Dams}

The corridor is still free of dams along the Paraguay and Paraná main channels but 45 dams have already been installed and around 135 more hydropower dams are being planned mostly in the Planalto region, impounding those rivers that drain into the Pantanal lowlands [139]. These dams are or will be installed on main tributaries, and although they are not located in the Corridor main channels, some could represent a major impacting factor. Most of the existing and proposed dams will yield between 1 and $30 \mathrm{MW}$, having reservoir areas less than $13 \mathrm{~km}^{2}$ and height ranging between 1 and $46 \mathrm{~m}$ (mean $17 \mathrm{~m}$ ) [140]. The construction of such dams could block between 25 and 
$32 \%$ of migratory routes in the upper basin [141]. If all upper Pantanal dams would be completed, this will control $40 \%$ of the tributary flow to the Pantanal and $38 \%$ of the flow from the Pantanal plain [142]. Current dams in the upper Pantanal are retaining 32\% of sediments and will retain up to $62 \%$ if all planned dams are installed [143]. In particular, the construction of the Manso Dam is of main concern, as it can regulate the flow of the Cuiaba River which supplies around $40 \%$ of the Paraguay River flow [144,145]. For most of the migratory species, dam construction will also isolate reproductive areas located upstream in the Paraguay and Cuiaba basins, implying a direct impact on the main corridor axis [139]. Pantanal dams may have important secondary effects by trapping sediment and promoting changes in the growth of submerged vegetation, and the composition and dynamics of planktonic communities. In addition, flow regulation by these small but numerous dams could put at risk the hydrological cycle of the lowlands and modify the landscape associated activities. [146] mentioned that in the Taquari River, for instance, flow variation has affected an area of $11,000 \mathrm{~km}^{2}$.

Attempts to install large dams in the main channel of the corridor have been oriented to the middle sector of the Corridor. This included the Middle Paraná Project which was planned for the middle section of the Paraná River in the XX century. This mega project required two reservoirs that should cover $7600 \mathrm{~km}^{2}$, making this chained system the largest in Latin America [147]. The main concern about this project was related to the impact on the local small-scale economies represented by artisanal and recreational fisheries that could be depleted if the free-flowing river would have been replaced by reservoirs, as has been noted in the Upper Paraná large dams in Brazil [90]. Previous studies pointed out the critical importance of Paraná and Paraguay main axes for fish reproduction of migratory species $[91,148,149]$, which in turn support many of the different fisheries along the corridor. The blockage of fish migratory routes could not have been mitigated by fish passages as they have shown low performance in dams of the Paraná River basin [150-153]. Fragmentation by dams could be not only structural but also functional as large reservoirs act also as an ecological barrier for downstream migrations of larvae and adult fish stages [154]. The project was largely sidelined by the joint action of local and international environmental organizations, and the 1994 reform of Argentina's constitution gave the provinces total control over their natural resources making this project unfeasible.

The influence of dams on the corridor can also be exerted by more than $150 \mathrm{dams}$ located in the upper Paraná basin, Brazil, where a volume of $260 \mathrm{~km}^{3}$ of water is retained in reservoirs [155]. It has been demonstrated that such dams can modify the hydrologic regime and attenuated the flood magnitude, particularly during dry periods $[61,156,157]$. This issue has been overlooked in previous environmental studies, despite that it is known that $75-80 \%$ of the flow entering into the corridor provides from this basin sector [158]. In addition, these authors noted the construction of dams in the upper Paraná basin up to $60 \%$ of the sediment load at the confluence with the Paraguay River.

\subsubsection{Dredging and Ports Construction}

Several studies conducted in the context of required channel modifications by rock outcrop removal, dredging, and straightening in the Paraguay River argued that an increase in the depth of the Paraguay River could accelerate water runoff and decrease the permanence of flooded areas in the Pantanal $[115,121,126,159,160]$. In addition, additional uncertainty exists on how the combination of climate change and hydrological change will impact the Pantanal and the rest of the corridor macro ecosystems in the long term [134].

According to [159] a depth increase of between 10 and $25 \mathrm{~cm}$ would result in a reduction in the wetland area of between 11.7 and 31.4\% respectively, although these estimates have not been corroborated or rectified by any subsequent studies. In addition, dredging impacts have been associated with the resuspension of contaminated sediments, but such an effect is expected to be negligible in the thalweg of the Corridor, where fine and medium sands represent the dominant substrates and clay and silt are transported as 
suspended sediments only [59]. Analyses carried out by [124] have shown that the sandy sediments of the riverbed have contaminant values well below the reference values.

Port development also involves dredging of an area with fine sediments that can be contaminated. Dredging of coastal sediments for port construction in suburban areas can remove sediments contaminated with PCBs, pesticides, PAHs, hydrocarbons, and heavy metals. In turn, the impacts of navigation will depend on the depth, width, and sinuosity of the river as well as the intensity of traffic. No less important, the construction of new ports and associated infrastructure is associated with the increase of shipping cargo, which in turn enhance the dispersal of exotic species by hull fouling [161,162].

\subsection{Water Use and Resource Exploitation}

\subsubsection{Navigation}

Navigation could generate severe impacts, even at a larger scale as is expected in the Pantanal area $[121,124]$ and in the Paraná Delta where main channels are narrow. The navigation of barge trains and large vessels exert different forces on the river system producing waves that upon reaching the shore resuspend sediments and erode the banks [163]. High and frequent waves produced by large barges and vessels produce not only coastal erosion and sediment resuspension but also interfere with fishing activities. During high water periods, waves can reach inside the islands and affect residents. Navigation and associated infrastructure have also been targeted as the main cause of exotic mollusks' invasion and dispersion, from the mouth of De La Plata River to the Pantanal $[164,165]$. Asian clam Corbicula fluminea and golden mussel Limnoperna fortunei have invaded the main rivers of the De la Plata basin [166] and have been detected in the Pantanal [167], without a clear perspective of their ecological consequences in the corridor $[168,169]$. Invasion of alien bivalves has shown a strong impact on indigenous aquatic communities worldwide [170]. The golden mussel is well known for the capacity of modifying benthic habitats $[169,171]$. If hydrological pulses were modified by flow regulations due to an increase in dam construction [172], these species could reach the Paraguay headwaters.

\subsubsection{Fishing Pressure}

Overall fishing effort in the corridor can be considered still moderate, even though there is more activity close to large urban centers (Corumba, Cuiaba, Asuncion, Rosario, etc.) Despite fishing pressure can be relevant in certain sectors, the corridor still exhibits healthy fisheries of migratory species, as shown by their maximum size and abundance. About 10,000 fishers are estimated for the Middle and Lower Paraná, and 7000 has ben calculated for the Pantanal [139] In the Paraná Delta, since 2000, the sabalo exportation industry has increased the historical low catches to values ranging between 15,000-20,000 tons annually, with similar values directed to the internal markets. The main threat of the exportation industry relies on considering fish just as a commodity, whereas social and economic benefits for the fishing communities are overlooked [113]. However, recreational fishing has a high relevance along the corridor and often represents the basis for extensive tourism and economic movements $[173,174]$. Over recent years, fisheries-related tourism in the Pantanal has decreased, triggering conflicts due to recent government regulations that consider recreational fisheries as a priority and attempts to ban artisanal fisheries. This activity shares almost the same species as artisanal fisheries, but the number of users and the impact on the catch is unknown, although probably greater than the produced by the artisanal fisheries. For instance, reported fish yield by the recreational fisheries in Upper Paraguay has been estimated as 1200 tons a year, and it has been estimated that the Pantanal is visited by about 140,000 recreational fishermen [111].

\subsection{Land Use}

\subsubsection{Forestry, Agriculture and Cattle Ranching}

Current economic development in some sectors of the corridor relies on transforming the riverscape by applying productive models derived from other agriculture regions 
without taking into account the corridor ecological setting. These land-use changes can result in floodplain fragmentation, wetland disconnection, exotic species introduction or invasion, increase in harmful algal blooms, and the continuing loss of habitats for biodiversity. The Pantanal area and surrounding landscape (The Cerrado), for example, have lost around 12,000 km² (Mato Grosso 35\%, Mato Grosso do Sul 67\%) of the original forest, and deforestation represents a current impact and major threat enhanced by livestock grazing [175]. Native vegetation and grass pastures in the uplands have been replaced by cultivated pastures to feed cattle, including exotic plant species. This trend has been mainly developed by non-traditional "pantaneiros", more interested in importing productive techniques to increase livestock density, but that is not compatible with the Pantanal environmental characteristics. In turn, cattle ranching in the Pantanal is the prevalent economic activity [176]. The total cattle herd in the Brazilian Pantanal has been estimated as 3.8 million heads, producing approximately 1 million calves per year [134]. In addition, water buffalo (Bubalus bubalis) is already established in several areas in the floodplain [136,177]. The conversion of native vegetation into crops and pasturelands in the highlands has been estimated near $60 \%$ and have accelerated erosion processes along the edges of the Pantanal, including an increase in sediment load in the rivers on the plains [178]. Unsustainable agroecosystems in the highlands resulted in higher inputs of water, sediment, and nutrients to the Pantanal lowlands, reducing its carrying capacity, resilience, and provision of ecosystem services [179]. Concern exists about the ecological impact of the increasing intensification of both cattle ranching and soybean production in the Pantanal due to technological advances and how these techniques can cope with flood pulses [180].

In the Paraná Delta ranching practices have favored dike development (polders) [181,182]. Dikes are constructed to mitigate or regulate floods' effects, and although they do not have effects on the longitudinal connectivity, they constitute a major disruptive factor affecting the lateral connectivity with inner island lakes and produce deep changes in land use and the isolation of floodplains [44,102]. Recently, [182] has calculated that the current surface transformed by dikes was 250,000 ha ( $12 \%$ of de Delta area), allowing the transformation of natural wetlands into forestry, livestock rearing, or urban areas. Cattle raising is the most important factor responsible for freshwater marsh conversion to pasture [181] and livestock farming is the second most important economic activity in the region [183]. This trend followed in some way the same logic as happens in the Pantanal by attempting to transform the Delta into highly productive land, transferring productive techniques used in the surrounding Pampean region ("Delta pampeanization"). In the Delta, livestock production is often combined with forestry so that livestock can remove weeds that may encourage fires. Cattle numbers in the Lower Delta increased by an order of magnitude in a single decade from 160,000 in 1997 to 1,500,000 heads in 2007, providing an intensive pressure factor on the wetlands' ecological integrity [184,185].

Large livestock densities also seriously threaten human, fish, and ecosystem health, being a source of organic and microbiological (pathogens and parasites) pollution. Veterinarian products applied to the livestock may be transferred to the watercourses by cattle manure runoff or during flooding events and introduce disease-causing pathogens through runoff from field deposition. The Pantanal is affected by cattle ranching pollution due to intensive cattle farming and pesticides [186]. However, this pollution source remains excluded from regulations or traditional impact assessment requirements. In addition, cattle and livestock, manure represents methane sources and their effects are potentiated as cattle ranching is moving from seasonal to year-round activity [187,188].

Wildfires do not represent a direct pressure on the corridor connectivity but are of paramount relevance due to their potential to modify the landscapes and ecological characteristics. In the case of aquatic habitats fire has the capacity of changing water quality due to an increase in suspended sediments, temperature, dissolvedoxygen [189]. In the corridor, the fire has been used historically as a management practice for wildlife hunting, to improve grass quality for cattle [181], and for the elimination of species with little or no 
forage value [190]. However, in the last years, fire hotspots increased dramatically with an unknown effect on wildlife. In 2008, during a long drought period, many simultaneous fires occurred on over 200,000 ha of the Paraná River Delta (7.2\%) [191]. This phenomenon repeated during 2020 when a total of 300,000 hectares were burned. Such extremes fires have coincided with extraordinary droughts that have made fishing difficult and could have promoted the illegal hunting of wildlife as a palliative resource.

\subsubsection{Shore Development and Urbanization}

The Hidrovía has generated important transformations and reconversions of the shoreline in the Paraná Delta sector due to the construction and expansion of port infrastructure. On a minor scale, similar problems have been observed in Santa Fe city [192] and could be expected to occur in the upper sector if the Hidrovía project is extended toward the Pantanal area. The expansion of the Hidrovía in the Middle and Lower Paraná sector would increase also social and environmental conflicts. The shore of the Lower Paraná River has suffered several important transformations due to the development of tourism, navigation, and trade activities in the last decades, and particularly since the beginning of the waterway concession [193].

\subsubsection{Aquaculture of Exotic Species}

Aquatic exotic species that inhabit the corridor include several taxa [138]. Fish, introductions have responded to commercial purposes to satisfy the market demands, but also the recreational fisheries preferences. Some paradigmatic examples are tambaquí (Colossoma macropomum) and tucunaré (Cichla ocellaris), which escaped from local hatcheries [194-196]. The tucunare is a large fish that can prey on native species, compete for food, and space disrupting ecological fish communities on a cascading scale in the trophic food chain [136]. The spread of this species could be also favored by an increase in water transparency due to sediment retention by dams. Recent legislation in Brazil would promote the introduction of more harmful exotic species and facilitate their expansion along the corridor [197,198].

\subsubsection{Urban Domestic, Industrial Effluent, Mining, and Agricultural Runoff}

Pesticides are a major impact because of the large Planalto areas of agricultural land surrounding the Pantanal [199]. Mining is also of critical economic importance for the region and occurs mainly at the fringes of the Pantanal [134]. Mercury was used in gold mining in the Poconé region and, despite that mining was forbidden, contamination of the food web has been detected $[200,201]$. Strong industrial and domestic contamination has been detected at the Caceres Lake-Tamengo channel complex in the Bolivia-Brazil border, where mining pollution by mercury is still common [202]. Domestic pollution is visible in the Cuiaba basin, and close to the other urban centers such as Asuncion, Corrientes, and Rosario. In the Middle and Lower Paraná, an increase in plastic levels has been detected $[203,204]$. In the Lower Paraná, high levels of metals and pesticides were also found, mostly carried by upland tributaries that cross-industrial areas [205,206]. As noted by different studies, Middle and Lower Paraná receive polluted inputs also from tributaries traversing across urban and industrialized areas, as well as extensive agricultural lands located in the hinterland [205].

\section{Legal and Institutional Framework}

National governments together with non-governmental organizations have developed conservation strategies to protect the wetland biodiversity for the whole basin such as De La Plata River Treaty Program Framework [207] and the Ramsar Regional Initiative [208], or covering the corridor partially, such as the Gran Chaco Americano Ecoregional Evaluation [209], the ZICOSUR initiative [210], and the Ecological Risk Assessment for the Paraguay River [208]. The Brazilian Pantanal has been declared as National Heritage Site since 1998 to assure the conservation of natural resources. Considered also as World Heritage Site and Biosphere Reserve by UNESCO, the Pantanal Mato-Grossense has three 
Ramsar sites [211]. Several parts of the Pantanal wetland are currently protected with the status of National Park, private reserve (RPPN), or indigenous reserve [136]. However, this is only $5.37 \%$ of the Pantanal's territory and less than $4 \%$ of the Planalto area corresponds to no-take reserves, far away from Aichi biodiversity targets of $17 \%$ [178]. In the Argentine sector of the corridor, nearly 100 protected areas are listed in the federal registry (which does not include private nature reserves), totaling more than $7000 \mathrm{~km}^{2}$, with the highest number of reserves located in the Paraná Delta [212]. These figures represent $14 \%$ of the corridor area, with wide differences in their management effectiveness based on protection category and administrative jurisdiction. Many have deficient budgets, lack of personnel, legal boundaries not delineated, which are indicative of a high potential for biodiversity degradation.

Differences in the legal framework and institutional organization among countries could appear as a weakness for the ecological conservation of the corridor, but at the same time, such divergences have contributed by limiting the development of large infrastructure works and associated territorial impacts. Paraguay is a unitary state with some sort of decentralization, whereas Bolivia, Brazil, and Argentina exhibit federal and decentralized forms of government with varying degrees of autonomy at provincial and municipal levels. For example, the ban on the construction of the Paraná Medio dams in the province of Entre Rios (Argentina) does not apply to other provinces in the Paraná basin, and this has led to the proposal of the construction of such dams upstream in other provinces. At present, the current state of conservation of the corridor is the result of isolated measures that have been adopted by the countries rather than as a result of integrated and coordinated crossborder policies. It is, therefore, necessary to consolidate the management and territorial governance and develop strategic conservation policies to make compatible a productive use of the corridor, preserving at the same time ecosystem services and biodiversity [210].

The current De La Plata Basin Treaty) represents a broad umbrella for promoting sustainable development, but it appears to be insufficient to maintain the ecological integrity of the corridor in the long term [213]. This treaty attempts to promote the harmonious development and physical integration of De La Plata Basin, based on several key environmental issues associated with water quality, sustainable use of the resources, and biodiversity conservation resources use]. However, major differences related to political and administrative structures, legal frameworks, institutional and technical capacities in the countries, may preclude accomplishing the treaty objectives. A serious limitation is the difficulty of articulating the agreements and organisms that exist in the basin, largely because there is no organization specifically dedicated to achieving this objective [214]. Different regional and national commissions and agencies that have incumbencies along the corridor do not develop fluid interactions, and generally, they have very different goals and missions related to the use and management of fishery resources, water use, navigation, hydroelectricity, river trade, etc. A similar problem was noted by [215] for the Uruguay River basin. Such context explains, for example, why the energy sector has been reluctant to sit down and discuss the scope of dam projects in upper Paraguay and their social and environmental consequences, and why the Middle Paraná dams project remains at the frontline of several energetic and water management agencies.

The four countries involved in the corridor have the basic legal tools to implement measures to protect water and biotic resources by adhering to the main international agreements addressing wetlands and biodiversity. Nevertheless, their implementation is non-existent, partial, or shows serious difficulties (Table 1). Although many harmful activities are prohibited by local legislation in most Latin American countries (e.g., introduction of non-native species, pollution, and overfishing), the most impacting ones are often rooted in official policies that foster hydropower development, water diversion, mining, agriculture, aquaculture without proper controls [198]. Development of multiple and often conflictive activities In addition, the development of multiple activities, often conflicting with each other, highlights the need to incorporate multidisciplinary visions into legal frameworks. For example, about $95 \%$ of Pantanal territories are privately owned and 
$80 \%$ of the lands are found on cattle ranches [101]. Forms of public access are limited in certain areas and are strongly restricted by cattle ranchers, mining companies, and forestry concessions, inducing conflicts with local communities. Similar conflicts are emerging more frequently in the Lower Paraná between fishermen and cattle ranchers when both use public lands or when ranchers prevent fishermen from accessing the floodplain lakes.

Table 1. The comparative legal framework of the main laws related to the protection of natural resources in the countries of the river corridor.

\begin{tabular}{ccccc}
\hline $\begin{array}{c}\text { Legal Frameworks } \\
\begin{array}{c}\text { Agencies of environmental policies } \\
\text { coordination }\end{array}\end{array}$ & Yrgentina & Bolivia & Brazil & Paraguay \\
\hline $\begin{array}{c}\text { Regulations on management and conservation } \\
\text { of water resources }\end{array}$ & Yes & Yes & Yes & Yes \\
\hline The specific law on the environment & Yes & Yes & No & No \\
\hline Law for the protection of the forest & Yes & Yes & Yes & Yes \\
\hline Law for the protection of fauna & Yes & Yes & Yes & Yes \\
\hline Adherence to the mandates of the CBD & Yes & Yes & Yes & No \\
\hline Adherence to Ramsar principles & Yes & Yes & Yes & Yes \\
\hline Specific law of protected areas & Yes & No & Yes & Yes \\
\hline Law for the protection of the environment & Yes & No & Yes & Yes \\
\hline Indigenous Rights and Policies Act & Yes & Yes & Yes & No \\
\hline Wetlands law & No & No & No & No \\
\hline Legislation on Planning and Land & Yes & Yes & Yes & Yes \\
\hline Management & No & No & No & Yes \\
\hline
\end{tabular}

\section{Conservation Challenges and Future Steps}

The outstanding characteristic of the Paraguay-Paraná corridor of conserving high ecological integrity [216], given by the existence of natural flood pulses and free connectivity that maintain valuable ecological functions and support its ecosystem services $[217,218]$, has led to propose this fluvial corridor as a global reference system [219]. Such a system can be used to gather valuable information to know how non-fragmented rivers behave in terms of their ecological processes. In a similar vein, it was suggested that the Paraguay River, as part of the corridor, may be considered as a natural model for restoration planning in similar systems of the tropical and subtropical zones in those rivers where natural conditions have lost [68]. The current status of the corridor suggests that it remains in a healthy state, with no irreversible impacts detected, but with increasing threats associated with the future economic development of the region. The marked contrast with the upper Paraná basin, given by the absence of longitudinal fragmentation, supports the notion that the system is resilient, sustaining high ecological integrity.

Conserving free-flowing transboundary rivers is a challenging task. In addition, to avoid fragmentation in any fluvial dimension, functional ecosystem integrity needs also to be maintained, with both short and long-term challenges differing among corridor sections. Probably the most important question that managers, conservationists, academia, NGOs, etc., should examine, is how to balance the socio-economic pressures of social and economic development with conservation needs [42], with acceptable threshold values for developing social and commercial activities without compromising natural process. In this context, it was suggested that the Pantanal is essentially at a crossroads due to increasing pressures on ecosystem functions, and a similar idea was proposed for the Middle and Lower Paraná River by [219]. Although recommendations have been put forward for the Pantanal to protect wetland connectivity, ecosystem services, water quality, 
and biodiversity [134], maintaining the ecological integrity of the entire corridor requires further and integrated efforts to develop management measures at different times and spatial scales. This is consistent with the perception that, in addition to some already detected impacts, there are perceived growing threats to the region. Conservation of the corridor in a healthy state should be associated with the conservation of wetlands and associated ecosystem services as a necessary basis to maintain the livelihood of many local populations $[103,104]$. These ecosystems stand out for the large number and diversity of benefits (environmental goods and services) they provide along the corridor. Thus, the loss of wetlands due to infrastructure development or habitat degradations could trigger changes in the different ecosystems that compose the corridor and, therefore, affect human well-being at different spatial scales.

The conservation of the corridor is closely tied to the future of Hidrovía, as the further development of this waterway can deeply impact hydrology, ecology, biodiversity, and the local communities, affecting their livelihoods $[115,159,220]$. However, the fate of the Hidrovía development is intertwined with geopolitical and commercial aspects that even exceed the scale of the Plata Basin. The economic viability of the project has different perceptions depending on the country. For Paraguay, the Hidrovía represents a key connection for agriculture exports and, not surprisingly, this country owns $75 \%$ de of barges navigating the corridor. For Brazil, however, Hidrovía is not yet a main priority, whereas Argentina would be the most benefited country in case of widening and extending the navigation channel in the lower sector of the waterway [221]. Although the project has shown a positive rate of return, problems of financing shared sectors between countries have not yet been resolved [120]. Different visions on the possible environmental impacts of the Hidrovía are also present, as there is a lack of common and agreed environmental norms and policies. Each country has approached the problem of this waterway from its own perspective and convenience, which has precluded generating common strategies to avoid political and institutional disagreements [222].

Conservation of the corridor's ecological integrity in the long term needs to consider predicted climate changes and their influence on hydrological variability. From 1970 to 2000, the Paraná and Paraguay flows have increased in parallel to changes in precipitation [223-226]. However, the increase in runoff has also been attributed to landuse changes due to the replacement of forests by agriculture [227,228]. This highlights the importance of considering how short-term land use influences the output of long-term climate change. Changes in flow intensity and amplitude may exert a paramount influence on disrupting the life cycles of different aquatic communities. In the De La Plata basin, the severe droughts of 2019 and 2020 have isolated the floodplain lakes for more than one year, impacting severely on fisheries and other activities.

Given the expected high hydrological variability in the basin, the environmental management of the corridor should not solely focus on the navigation channel capacity but also provide conditions to assure floodplain connectivity. Developing and applying environmental flow criteria is a challenging issue. Few methods described in the literature seem to be applicable for large floodplain rivers [229]. Simplistic, static rules used in hydraulic-based methods are inappropriate to capture the requirements of highly variable floodplain rivers. Methods such as the Instream Flow Methodology and its cornerstone, PHABSIM, the physical habitat simulation model $[230,231]$, are unsuitable for large river systems. The distribution of aquatic organisms in complex floodplains and anabranches, responds more to environmental gradients rather than focal point values in instream habitats, invalidating the use of habitat suitability curves [22]. Environmental flow should be defined based on merging sustainable water management with social demands and environmental requirements $[232,233]$.

Multiple studies on different sectors of the Corridor, particularly in the Pantanal area, have failed to integrate the multiple interconnections between state, society, and nature [42], so an hydrosocial territory vision is pending [234]. Under this perspective, water management should simultaneously take into account social, economic, and environmental values 
and demands. Such an approach could help understand conflicts associated with water control, regulations and uses, and how they are linked to water-power structures, and governance. The energy, agriculture, hydraulic engineering, and water markets sectors often consider water as an economic good that should be managed efficiently [235]. However, water in transboundary rivers also provides shared livelihood resources and critical sites for biodiversity conservation [236]. The large number of small-scale fisheries dispersed along the corridor can be conceived as a mosaic of socio-ecological systems [237-239]. In this context, the conception of hydrosocial territories needs adaptive governance mechanisms [240], which in turn requires a better understanding of the functioning of these complex networks in transboundary systems [241].

Strategies for corridor conservation should strengthen the link between science, traditional knowledge, and policymaking. The extraordinary length of the corridor and the different conflicts and problems across scales require a strong involvement of people and institutions other than only the academia and governmental institutions. In this context, citizen science [242,243] and public participation in scientific research [244] could play a critical role in filling the gap between sectors. This approach, still poorly exercised in the corridor, has been suggested by [43] based on incorporating new players to solve the disputes in the Pantanal. Socio-economic relations in the corridor have undergone significant changes in the last decades defining new environmental management and conflicts associated with socioeconomic conditions and some actors associated with water and land use have gained more power and influence. Stakeholder participation through public and private institutions can provide also more transparency to decision-making processes and more effective conservation measures [245]. A noticeable example was the actions carried out in the 1980s to stop the Paraná Medio dams. Similarly, different social organizations and rightsholders of the Pantanal area, mainly at Caceres Port, have played a critical role in litigating against the expansion of the waterway and the construction of more dams in the Planalto region. The application of municipal or even provincial ordinances that impact directly on local people represent valuable tools for preserving local biodiversity, preserve coastal wetland areas habitat connectivity, and sustain local livelihoods, etc.

On the other hand, the increase of public involvement will also contribute to reduce the persistent rift between the productive development and the conservationist sectors and facilitate the comprehension of the scope of the projects. This gap has generated concepts and predictions that have not been handled or supported by adequate data. This has been observed in the case of the Hidrovía, where the expected impacts by the first evaluation studies, were not scientifically verified or monitored, wasting the opportunity to use this information to prevent or mitigate possible future impacts or detect incoming threats. A comparison of current knowledge since such assessments at the end of the 20th century suggests that despite the numerous environmental and academic studies developed over the last 30 years, not so much progress has been made in gathering key environmental information considering this cross-border, and controversial project. Exhaustive analyses of cumulative effects are still lacking to understand how cascading effects can impact the corridor ecosystems and their people's livelihoods. The planned expansion of the Hidrovía will, therefore, take place in a scenario that does not differ too much from the one several decades ago. It is necessary to avoid extrapolating information from other waterways often of very distinct characteristics and with different species or stakeholders, and where the impacts of dredging and navigation may not be necessarily similar. Scientific and technical studies should be, therefore, oriented to elucidate the potential impacts of expected projects, rather than focusing on gathering only basic and descriptive information without a strong relationship to them.

Finally, as power relationships among main players vary along the Corridor, the social perception of how development initiatives can affect the interests of people and institutions can be highly variable. For instance, whereas in the upper Paraguay basin the potential effects of the Hidrovía expansion have represented the main concern and source of tensions between the productive and environmentalist sector, in the Paraná 
Delta, coastal urbanizations, fishing pressure for exportation, and intensive cattle and agriculture practices have concentrated the main controversies. As noted by $[119,138]$, it is necessary to gather a better understanding of stakeholder values, preferences, and demands that the corridor provides. Many actors who use the river space and its resources have developed a fine capacity to perceive changes and transformations and be able to detect them at a local scale [246]. In this context, performing participatory mapping activities could represent also a suitable strategy for identifying and spatialize fluvial territories of important socio-economic and environmental relevance and help to setting management strategies and establishing priorities for solving community conflicts [247]. This approach would contribute to developing sound territorial ordination planning considering the fluvial spaces as a dynamic but critical component of the landscape in which several ecosystem services take place. Past environmental impact studies in the corridor have paid little attention to the local scale, and its importance in providing criteria for environmental decision-making has been underestimated by management agencies. In the Paraná Delta, previous attempts to develop a land-use planning framework $[248,249]$ ignored the need to include the fluvial territory as a core concept for this region, focusing mostly on terrestrial productive activities $[250,251]$.

\section{Conclusions}

The Paraguay-Paraná corridor, as a free-flowing system, exhibits a potential high potential resilience to disturbances, being this feature strongly related to its free connectivity between the main channels and floodplains and lack of longitudinal or severe lateral fragmentation. The conservation of the corridor will require, however, different actions and policies oriented to support sustainable livelihoods, biodiversity, and ecosystem services that large river systems provide. Unsustainable practices by land and water uses can impact and provoke multiple disturbances and negatively affect the structure and functioning of freshwater ecosystems. In addition, the corridor may be highly vulnerable to unfavorable climatic conditions associated with extended severe droughts that can influence the conservation of functional floodplain ecosystems.

A transversal axis to several of the legal instruments and mandates of institutions that have interference on the management and administration of the resources of the corridor should be the conservation of the extensive wetlands and related ecosystem services that represent a distinctive factor in most of the corridor length and make it more resilient than impaired large river systems. Although the Pantanal is recognized as one of the most iconic wetlands in the world, conservation policies must be extended to the entire wetland belt that integrates the corridor. Maintenance of the ecological integrity will require that the countries start discussing how to support durable rivers protection and restoration measures, and that current and planned infrastructure initiatives become compatible with sustainable social and economic development. One of the most conflicting but critical aspects for the conservation of the corridor in a durable state is the need to improve and articulate regulatory frameworks that operate at different scales. The different political and institutional scenarios of the countries, and still weak water governance mechanisms, make it difficult to impose articulated measures for the protection and management of resources based on local, regional, and transboundary priorities.

Future efforts in gathering more environmental information should be oriented to cope with predicted impacts or planned infrastructure works. The development of the first EIAs associated with the Hidrovía has not been very positive because they lack adequate environmental and ecological information. Most of the studies related to this project have been questioned due to the lack of social, economic, and environmental integration and verified information associated with the ecological effects of dredging, navigation, and ports development. As this project is considered a strategic initiative in the corridor that attempts to integrate transboundary interests and demands of the different productive sectors, its positive and negative impacts at different levels will continue to have paramount importance. 
Central for the corridor conservation is the need to tackle a strong interdisciplinary vision, beyond a traditional engineering and hydrological perspective. This implies avoiding thinking of the corridor as a water highway for only commercial purposes, but perceiving it as a connector that supports social benefits to local communities. In this sense, understanding the corridor under a hydrosocial perspective would contribute to improving the discussion of key issues that influence the Corridor's socio-ecological status. In this context, major progress could be expected if a multiscale integrative approach is adopted to articulate measures and actions at local, regional, and cross-border levels. Finally, a strengthening of the communication between different social sectors will help to change the perception that many projects planned for the corridor may have a high impact without having the necessary information, or avoid that society cannot recognize environmentally incompatible proposals. This strategy will facilitate more creative responses and more effective solutions to resolve the growing social and environmental conflicts that are occurring along the Paraguay-Paraná corridor.

Author Contributions: Conceptualization, C.R.M.B.; investigation, C.R.M.B. and P.G.M.; writingoriginal draft preparation, C.R.M.B.; writing-review and editing, C.R.M.B. and P.G.M.; visualizations, C.R.M.B. and P.G.M.; funding acquisition, C.R.M.B. All authors have read and agreed to the published version of the manuscript.

Funding: This research was funded by FONCYT grant number PICT2016-0927 (C.R.M.B.), DOB Ecology-Netherlands for Wetlands International LAC "Corredor Azul” Project. The IUCN Commission of Ecosystem Management (CEM) covered publication costs.

Institutional Review Board Statement: Not applicable.

Informed Consent Statement: Not applicable.

Data Availability Statement: Not applicable.

Acknowledgments: We want to acknowledge Angela Andrade (IUCN CEM chair) for securing and approving funds for publication.

Conflicts of Interest: The authors declare no conflict of interest. The funders had no role in the design of the study; in the writing of the manuscript, or in the decision to publish the results.

\section{References}

1. Dollar, E.S.; James, C.S.; Rogers, K.H.; Thomas, M.C. A framework for interdisciplinary understanding of rivers as ecosystems. Geomorphology 2007, 89, 147-162. [CrossRef]

2. Rodriguez-Iturbe, I.; Muneepeerakul, R.; Bertuzzo, E.; Levin, S.; Rinaldo, A. River networks as ecological corridors: A complex systems perspective for integrating hydrologic, geomorphologic, and ecologic dynamics. Wat. Resour. Res. 2009, 45, W01413. [CrossRef]

3. Kondolf, G.M.; Boulton, A.J.; O’Daniel, S.; Poole, G.C.; Rahel, F.J.; Stanley, E.H.; Wohl, E.; Bång, A.; Carlstrom, J.; Cristoni, C.; et al. Process-based ecological river restoration: Visualizing three-dimensional connectivity and dynamic vectors to recover lost linkages. Ecol. Soc. 2006, 11, 5. Available online: http:/ /www.ecologyandsociety.org/vol11/iss2/art5/ (accessed on 1 April 2021). [CrossRef]

4. WWF. Free-Flowing Rivers: Economic Luxury or Ecological Necessity? World Wildlife Fund: Zeist, The Netherlands, 2006. Available online: https:/ / wwf.panda.org/ (accessed on 1 March 2021).

5. Rouget, M.; Cowling, R.M.; Lombard, A.T.; Knight, A.T.; Kerley, G.I. Designing large scale conservation corridors for pattern and process. Conserv. Biol. 2006, 20, 549-561. [CrossRef]

6. Stanford, J.A.; Ward, J.V. The hyporheic habitat of river ecosystems. Nature 1988, 335, 64-66. [CrossRef]

7. Stanford, J.A.; Ward, J.V. An ecosystem perspective of alluvial rivers: Connectivity and the hyporheic corridor. J. N. Am. Benthol. Soc. 1993, 12, 48-60. [CrossRef]

8. Pringle, C.M. Hydrologic connectivity and the management of biological reserves: A global perspective. Ecol. Appl. 2001, 11, 981-998. [CrossRef]

9. Harvey, J.; Gooseff, M. River corridor science: Hydrologic exchange and ecological consequences from bedforms to basins. Water Resour. Res. 2015, 51, 6893-6922. [CrossRef]

10. Wantzen, K.M.; Drago, E.; da Silva, C.J. Aquatic habitats of the Upper Paraguay River-Floodplain system and parts of the Pantanal (Brazil). Ecohydrol. Hydrobiol. 2005, 5, 107-126.

11. Lexartza-Artza, I.; Wainwright, J. Hydrological connectivity: Linking concepts with practical implications. Catena 2009, 79, 146-152. [CrossRef] 
12. Petts, G.E.; Bravard, J.R. A drainage basin perspective. In Fluvial Hydrosystems; Petts, G.E., Amoros, C., Eds.; Chapman \& Hall: London, UK, 1996; pp. 13-36.

13. Vannote, R.L.; Minshall, G.W.; Cummins, K.W.; Sedell, J.R.; Cushing, C.E. The river continuum concept. Can. J. Fish. Aquat. Sci. 1980, 37, 130-137. [CrossRef]

14. Ward, J.V.; Stanford, J.A. The serial discontinuity concept of lotic ecosystems. In Dynamics of Lotic Ecosystems; Fontaine, T.D., Barell, S.M., Eds.; Ann Arbor Science Publishers: Ann Arbor, MI, USA, 1983; pp. 29-34.

15. Junk, W.J.; Bayley, P.B.; Sparks, R.E. The Flood Pulse Concept in River Floodplain Systems. Can. Spec. Publ. Fish. Aquat. Sci. 1989, $106,110-127$.

16. Junk, W.J.; Wantzen, K.M. The Flood Pulse Concept: New Aspects, Approaches, and Applications-An Update. In Proceedings of the 2nd Large River Symposium (LARS), Pnom Penh, Cambodia, 11-14 February 2003; Welcomme, R., Petr, T., Eds.; RAP Publication 2004/16. Food and Agriculture Organization, FAO Regional Office for Asia and the Pacific: Bangkok, Thailand; Me-kong River Commission: Vientiane, Laos, 2004; pp. 117-149.

17. Fausch, K.D.; Torgersen, C.E.; Baxter, C.V.; Li, H.W. Landscapes to riverscapes: Bridging the gap between research and conservation of stream fishes. Bioscience 2002, 52, 483-498. [CrossRef]

18. Richter, B.D.; Baumgartner, J.V.; Powell, J.; Braun, D.P. A method for assessing hydrologic alteration within ecosystems. Conserv. Biol. 1996, 10, 1163-1174. [CrossRef]

19. Poff, N.L.; Allan, J.D.; Bain, M.B.; Karr, J.R.; Prestegaard, K.L.; Richter, B.D.; Sparks, R.E.; Stromberg, J.C. The natural flow regime: A paradigm for river conservation and restoration. Bioscience 1997, 47, 769-784. [CrossRef]

20. Petts, G.E.; Amoros, C. The fluvial hydrosystem. In Fluvial Hydrosystems; Petts, G.E., Amoros, C., Eds.; Chapman \& Hall: London, UK, 1996; pp. 1-12.

21. Thorp, J.H.; Thoms, M.; Delong, M.D. The riverine ecosystem synthesis: Biocomplexity in river networks across space and time. River Res. Appl. 2006, 22, 123-147. [CrossRef]

22. Nestler, J.; Goodwin, R.S.; Pompeu, P.; Silva, L.; Baigún, C.; Oldani, N. The river machine: A template for fish move-ment and habitat, fluvial geomorphology, fluid dynamics, and biogeochemical cycling. River Res. Appl. 2012, 28, 490-512. [CrossRef]

23. Thomaz, S.M.; Bini, L.M.; Bozelli, R.L. Floods increase similarity among aquatic habitats in river-floodplain systems. Hydrobiologia 2007, 579, 1-13. [CrossRef]

24. Ward, J.V.; Tockner, K.; Uehlinger, U.; Malard, F. Understanding natural patterns and processes in river corridors as the basis for effective river restoration. Regul. Rivers: Res. Manag. 2001, 17, 311-323. [CrossRef]

25. Wiens, J. Riverine landscapes: Taking landscape ecology into the water. Freshw. Biol. 2002, 47, 501-515. [CrossRef]

26. Tischendorf, L.; Fahrig, L. On the usage and measurement of landscape connectivity. Oikos 2000, 90, 7-19. [CrossRef]

27. Fullerton, A.H.; Burnett, K.M.; Steel, E.A.; Flitcroft, R.L.; Pess, G.R.; Feist, B.E.; Torgersen, C.E.; Miller, D.J.; Sander-son, B.L. Hydrological connectivity for riverine fish: Measurement challenges and research opportunities. Freshwat. Biol. 2010, 55, 2215-2237. [CrossRef]

28. Neiff, J.J.; Casco, S.L.; Cozar Cabañas, A.; Poi, A.S.; Ubeda, B.; Ricaurte, L.F.; Mendiondo, E. Connectivity of river floodplains-The case of Ibera wetlands after 10,000 years of isolation from Parana River. Wetl. Sci. Pract. 2020, 37, 267-282.

29. Pringle, C. The need for a more predictive understanding of hydrologic connectivity. Aquat. Conserv. Mar. Freshw. Ecosyst. 2003, 13, 467-471. [CrossRef]

30. Ward, J.V.; Tockner, K.; Arscott, D.B.; Claret, C. Riverine landscape diversity. Freshw. Biol. 2002, 47, 517-539. [CrossRef]

31. Tetzlaff, D.; Soulsby, C.; Bacon, P.J.; Youngson, A.F.; Gibbins, C.; Malcolm, I.A. Connectivity between landscapes and riverscapesA unifying theme in integrating hydrology and ecology in catchment science? Hydrol. Proc. 2007, 21, 1385-1389. [CrossRef]

32. Valbo-Jørgensen, J.; Marmulla, G.; Welcomme, R.L. Migratory Fish Stocks in Transboundary Basins-Implications for Governance, Management and Research. In Rescue of Sturgeon Species in the Ural River Basin; Lagutov, V., Ed.; NATO Science for Peace and Security Series C: Environmental Security; Springer: Dordrecht, The Netherlands, 2008. [CrossRef]

33. Nilsson, C.; Reidy, C.A.; Dynesius, M.; Revenga, C. Fragmentation and Flow Regulation of the World's Large River Systems. Science 2005, 308, 405-408. [CrossRef]

34. McCully, P. Silenced Rivers: The Ecology and Politics of Large Dams; Zed Books: London, UK, 1996.

35. ICOLD (International Commission on Large Dams). World Register of Dams. 2011. Available online: http://www.icold-cigb.org (accessed on 10 November 2020).

36. Winemiller, K.O.; McIntyre, P.B.; Castello, L.; Fluet-Chouinard, E.; Giarrizzo, T.; Nam, S.I.; Baird, G.; Darwall, W.; Lujan, N.K.; Harrison, I.; et al. Balanc-ing hydropower and biodiversity in the Amazon, Congo, and Mekong. Science 2016, 351, 128-129. [CrossRef] [PubMed]

37. Latrubesse, E.M.; Arima, E.Y.; Dunne, T.; Park, E.; Bakerm, V.; d’Horta, F.M.; Wight, C.; Wittman, F.; Zuanon, J.; Baker, P.A.; et al. Damming the rivers of the Amazon basin. Nature 2017, 546, 363-369. [CrossRef] [PubMed]

38. Anderson, E.P.; Jenkins, C.N.; Heilpern, S.; Maldonado-Ocampo, J.A.; Carvajal-Vallejos, F.M.; Encalada, A.C.; Rivadeneira, J.F.; Hidalgo, M.; Cañas, C.M.; Ortega, H.; et al. Fragmentation of Andes-to-Amazon connectivity by hydropower dams. Sci. Adv. 2018, 4, eaao1642. [CrossRef]

39. Grill, G.; Lehner, B.; Lumsdon, A.; MacDonald, G.K.; Zarfl, C.; Lierman, C.R. An index-based framework for assessing patterns and trends in river fragmentation and flow regulation by global dams at multiple scales. Environ. Res. Lett. 2015, 10, 015001. [CrossRef] 
40. Agostinho, A.A.; Gomes, L.C.; Pelicice, F.M. Ecologia e Manejo de Recursos Pesqueiros em Reservatórios do Brasil; Universidade Estadual de Maringa: Maringa, Brasil, 2007.

41. Junk, W.J.; da Cunha, C.N. Pantanal: A large South American wetland at a crossroads. Ecol. Eng. 2005, 24, 391-401. [CrossRef]

42. Ioris, A.A. Rethinking Brazil's Pantanal wetland: Beyond narrow development and conservation debates. J. Environ. Develop. 2013, 22, 239-260. [CrossRef]

43. Schulz, C.; Whitney, B.S.; Rossetto, O.C.; Neves, D.M.; Crabb, L.; Oliveira, E.C.; Lima, P.L.; Afzal, M.; Laing, A.; de Souza, L.C.; et al. Physical, ecological and human dimensions of environmental change in Brazil's Pantanal wetland: Synthesis and research agenda. Sci. Total Environ. 2019, 687, 1011-1027. [CrossRef]

44. Baigún, C.R.; Puig, A.; Minotti, P.G.; Kandus, P.; Quintana, R.; Vicari, R.; Oldani, N.; Nestler, J.M. Resource use in the Paraná River Delta (Argentina): Moving away from an ecohydrological approach? Ecohydrol. Hydrobiol. 2008, 8, 245-262. [CrossRef]

45. Quirós, R.; Bechara, J.A.; Resende, E.K. Fish diversity and ecology, habitats and fisheries for the un-dammed riverine axis Paraguay-Parana-Rio de la Plata (Southern South America). Aquat. Ecosyst. Health Manag. 2007, 10, 187-200. [CrossRef]

46. Minotti, P.G. The Paraná-Paraguay Fluvial Corridor (Argentina). In The Wetland Book; Finlayson, C., Milton, G., Prentice, R., Davidson, N., Eds.; Springer: Dordrecht, The Netherlands, 2018. [CrossRef]

47. Abell, R.; Thieme, M.; Revenga, C.; Bryer, M.; Kottelat, M.; Bogutskaya, N.; Coad, B.; Mandrak, N.; Contreras-Balderas, S.; Bussing, W.; et al. Freshwater ecoregions of the world: A new map of biogeographic units for freshwater biodiversity conservation. BioScience 2008, 58, 403-414. [CrossRef]

48. Neiff, J.J.; de Neiff, A.P.; Casco, S. Importancia ecológica del corredor fluvial Paraguay-Paraná como contexto de manejo sostenible. In Humedales Fluviales de América del Sur; Hacia un manejo sustentable; Capatto, J., Petean, J., Eds.; Fundacion Proteger: Buenos Aires, Argentina, 2005; pp. 1932-2010.

49. Minotti, P.; Ramonell, C.; Kandus, P. Regionalización del corredor fluvial Paraná-Paraguay. In Inventario de los Humedales de Argentina; Sistemas de paisajes de humedales del Corredor Fluvial Paraná-Paraguay; Benzaquén, L., Blanco, D.E., Bó, R.F., Kandus, P., Lingua, G.F., Minotti, P., Quintana, R.D., Sverlij, S., Vidal, L., Eds.; Secretaría de Ambiente y Desarrollo Sustentable de la Nación: Buenos Aires, Argentina, 2013; pp. 33-90.

50. Junk, W.J. The Amazon and the Pantanal: A critical comparison and lessons for the future. In The Pantanal: Understanding and Preserving the World's Largest Wetland; Swarts, F.A., Ed.; Paragon House: St Paul, MN, USA, 2000; pp. 211-224.

51. Alho, C.J.R. The Pantanal. In The World's Largest Wetlands-Ecology and Conservation; Fraser, L.H., Keddy, P.A., Eds.; Cambridge University Press: Cambridge, MA, USA, 2005; pp. 203-271.

52. Da Silva, C.; Pierre Girard, P. New challenges in the management of the Brazilian Pantanal and catchment area. Wetl. Ecol. Manag. 2004, 12, 553-561. [CrossRef]

53. Junk, W.J.; da Cunha, C.N.; Wantzen, K.M.; Petermann, P.; Strüssman, C.; Marques, M.I.; Adis, J. Biodiversity and its conservation in the Pantanal of Mato Grosso, Brazil. Aquat. Sci. 2006, 68, 278-309. [CrossRef]

54. Calheiros, D.F.; Oliveira, M.D. O rio Paraguai e sua planície de inundação: O Pantanal Mato-Grossense. Ciênica e Ambiente 2010, $14,113-130$.

55. Alho, C.J.R.; Silva, J.S.V. Effects of severe floods and droughts on wildlife of the Pantanal wetland (Brazil)—A review. Animals 2012, 2, 591-610. [CrossRef]

56. Bravo, J.M.; Collischon, W.; da Paz, A.R.; Allasia, D.; Domecq, F. Impact of projected climate change on hydrologic regime of the Upper Paraguay River basin. Clim. Chang. 2013, 127, 27-41. [CrossRef]

57. Sambrook Smith, T.G.; Best, J.L.; Leroy, J.; Orfeo, O. The alluvial architecture of a suspended sediment dominated meandering river: The Rio Bermejo, Argentina. Sedimentology 2016, 63, 1187-1208. [CrossRef]

58. Orfeo, O.; Steveaux, J. Hydraulic and morphological characteristics of middle and upper reaches of the Paraná River (Argentina and Brazil). Geomorphology 2002, 44, 309-322. [CrossRef]

59. Amsler, M.L.; Prendes, H.H. Transporte de sedimentos y procesos fluviales asociados. In El Río Paraná en su Tramo Medio; Paoli, C.M., Schreider, M., Eds.; Universidad Nacional del Litoral: Santa Fe, Argentina, 2000; pp. 233-306.

60. Drago, E. The physical dynamics of the river-lake floodplain system. In The Middle Paraná River; Iriondo, M.H., Paggi, J.C., Parma, M.J., Eds.; Springer: Berlin/Heidelberg, Germany, 2007; pp. 83-122.

61. Ramonell, C.G.; Amsler, M.L.; Toniolo, L. Shifting modes of the Paraná River thalweg in its Middle-Lower reaches. Z. Geomorphol. Suppl. 2002, 129, 129-142.

62. Latrubesse, E. Anabranching rivers as the end member for the concept of channel continuum in large rivers. Geomorphology 2008, $96,123-149$.

63. Drago, E. Geomorphology of large alluvial rivers: Lower Paraguay and Middle Paraná. Interciencia 1990, 15, $378-387$.

64. Malvárez, A.I. El Delta del Paraná como mosaico de humedales. In Tópicos Sobre Humedales Subtropicales y Templados de Sudamérica; Malvárez, A.I., Ed.; MAB-UNESCO/ORCYT: Montevideo, Uruguay, 1999.

65. Kandus, P.; Quintana, R.D.; Bó, R.F. Patrones de Paisaje y Biodiversidad del Bajo Delta del Río Paraná; Mapa de Ambientes; Pablo Casamajor Ediciones: Buenos Aires, Argentina, 2006.

66. Marchetti, Z.Y.; Latrubesse, E.M.; Pereira, M.S.; Ramonell, C.G. Vegetation and its relationship with geomorphologic units in the Parana River floodplain, Argentina. J. S. Am. Earth Sci. 2013, 46, 122-136. [CrossRef] 
67. De Cunha, C.N.; Fernandez Piedade, M.T.; Junk, W.J. Classificação e Delineamento das Áreas Úmidas Brasileiras e de Seus Macrohabitats; EdUFMT: Cuiaba, Brasil, 2015.

68. Drago, E.C.; Wantzen, K.M.; Paira, A.R. The lower Paraguay River floodplain habitats in the context of the fluvial hydrosystem approach. Ecohydrol. Hydrobiol. 2008, 8, 125-142. [CrossRef]

69. CIC. Inventario de las Regiones de Humedales de la Cuenca del Plata. Comité Intergubernamental Coordinador de los Países de la Cuenca del Plata, OEA. 2017. Available online: https:/ / cicplata.org/es/documentos-tematicos/ (accessed on 10 April 2021).

70. Neiff, J.J.; de Neiff, A.P.; Canon Veron, M. The role of vegetated areas on fish assemblage of the Paraná River flood-plain: Effects of different hydrological conditions. Neotrop. Ichthyol. 2009, 7, 39-48. [CrossRef]

71. Neiff, J.J. Ideas para la interpretación ecológica del Paraná. Interciencia 1990, 5, 424-441.

72. Marchese, M.R.; de Drago, I.D.E.; Drago, E.C. Benthic macroinvertebrates and physical habitat rela-tionships in the Paraná river-floodplain system. In Ecohydrology of South American Rivers and Wetlands; Special Publication 6; McClain, M.M., Ed.; International Association of Hydrological Sciences: Wallingford, UK, 2002; pp. 111-132.

73. De Drago, I.E.; Marchese, M.R.; Wantzen, K.M. Benthos of a large neotropical river: Spatial patterns and species assemblages in the Lower Paraguay and its floodplains. Arch. Hydrobiol. 2004, 160, 347-374. [CrossRef]

74. Marchese, M.R.; Wantzen, K.M.; de Drago, I.E. Benthic invertebrate assemblages and species diversity patterns of the upper Paraguay River. River Res. Appl. 2005, 21, 485-499. [CrossRef]

75. Zilli, F.; Montalto, L.; Marchese, M.R. Benthic invertebrate assemblages and functional feeding groups in the Paraná River floodplain (Argentina). Limnologica 2008, 38, 159-171. [CrossRef]

76. Marchese, M.R.; de Drago, I.E. Benthos of the lotic environment in the Middle Parana River systems: Transverse zonation. Hydrobiologia 1992, 237, 1-13. [CrossRef]

77. Abrial, E.; Espínola, L.A.; Amsler, M.L.; Rabuffetti, A.P.; Latosinski, F.G.; Szupiany, R.N.; Blettler, M.C.M. Fish structure in channel networks of a large anabranching floodplain: Effect of isolation/connection processes. Water Resour. Res. 2019, 55, 10993-11000. [CrossRef]

78. Stoffels, R.J.; Rehwinkel, R.A.; Price, A.E.; Fagan, W.F. Dynamics of fish dispersal during river-floodplain connec-tivity and its implications for community assemble. Aquat. Sci. 2016, 78, 355-365. [CrossRef]

79. Espinola, L.A.; Abrial, E.; Rabuffetti, A.P.; Simoes, N.R.; Amsler, M.L.; Blettter, M.; Eurich, M.; Paira, A.R. Discrimi-nation of hydrologic variations for spatial distribution of fish assemblage in a large subtropical temperate river. Ecohydrology 2020, 13, e2163. [CrossRef]

80. Espinola, L.A.; Rabuffetti, A.P.; Abrial, E.; Masler, M.L.; Bletter, M.C.; Paira, A.R.; Simoes, N.R.; Santos, L.N. Response of fish assemblage structure to changing flood and flow pulses in a large subtropical river. Mar. Freshw. Res. 2016, 68, 319-330. [CrossRef]

81. Poully, M.; Rodriguez, M.A. Determinism of fish assemblage structure in Neotropical floodplain lakes: Influence of internal and landscape lake conditions. In Proceedings of the Second International Symposium on the Management of Large Rivers for Fisheries, Phnom Penh, Cambodia, 11-14 February 2003; RAP Publication 2004/17. Welcomme, R., Petr, T., Eds.; FAO Regional Office for Asia and the Pacific: Bangkok, Thailand, 2004; Volume II, pp. 243-266.

82. Bonetto, A.A.; de Yuan, E.C.; Pignalberi, C.; Oliveros, O. Ciclos hidrológicos del río Paraná y las poblaciones de peces contenidos en las cuencas temporarias de su valle de inundación. Physis 1969, 29, 213-224.

83. Bonetto, A.A.; Neiff, J.J.; di Persia, D.H. The Paraná River system. In The Ecology of River Systems; Monographiae Biologicae Volume 60; Davies, B.R., Walker, K.F., Eds.; Springer: Dordrecht, The Netherlands, 1986.

84. Abrial, E.; Rabuffetti, A.P.; Espínola, L.A.; Amsler, M.L.; Blettler, C.M.; Paira, A.R. Influence of hydrological changes on the fish community in two lotic environments of the Middle Paraná Floodplain, Argentina. Aquat. Ecol. 2014, 48, 337-349. [CrossRef]

85. Agostinho, A.A.; Thomaz, S.M.; Gomes, L.C. Threats for biodiversity in the floodplain of the Upper Paraná River: Effects of hydrological regulation by dams. Ecohidrol. Hidrobiol. 2004, 4, 255-256.

86. De Yuan, E.C.E.; Oldani, N.O.; Oliveros, O.; Pignalberi de Hassan, C. Aspectos limnológicos de ambientes próximos a la ciudad de Santa Fe (Paraná Medio): Poblaciones de peces ligados a la vegetación. Neotropica 1984, 30, 127-139.

87. Delariva, R.L.; Agostinho, A.A.; Nakatani, K.; Baumgartner, G. Ichthyofauna associated to aquatic macrophytes in the upper Parana River floodplain. Revista Unimar 1994, 16 (Suppl. 3), 41-60.

88. Meschiatti, A.J.; Arcifa, M.S.; Fenerich-Verani, N. Fish communities associated with macrophytes in Brazilian floodplain lakes. Environ. Biol. Fishes 2000, 58, 133-143. [CrossRef]

89. Agostinho, A.A.; Thomaz, S.M.; Minte-Vera, C.V.; Winemiller, K.O. Biodiversity in the high Paraná River flood-plain. In Biodiversity in Wetlands: Assessment, Function and Conservation; Gopal, B., Junk, W.J., Davis, B., Eds.; Backhuys Publishers: Leiden, The Netherlands, 2018; pp. 89-118.

90. Agostinho, A.A.; Gomes, L.C.; Ferreira Julio, H., Jr. Relação entre macrófitas aquáticas e fauna de peixes. In Ecología e Manejo de Macrófitas Aquáticas; Thomaz, S.M., Bini, L.M., Eds.; EDUEM: Maringá, Brasil, 2000; pp. 261-279.

91. Resende, E.K. Migratory Fishes of the Paraguay-Paraná Basin, excluding the Upper Paraná Basin. In Migratory Fish of South America; Biology, fisheries and conservation status; Carolsfeld, J.B., Harvey, B., Ross, C., Baer, A., Eds.; World Bank: Washington, DC, USA; World Fisheries Trust: Victoria, BC, Canada; International Development Research Centre: Ottawa, ON, Canada; The International Bank for Reconstruction and Development/The World Bank: Washington, DC, USA, 2003; pp. 99-156. 
92. Resende, E.K. Ecology of Pantanal fish. In The Pantanal: Ecology, Biodiversity and Sustainable Management of a Large Neotropical Seasonal Wetland; Junk, W.J., Girard, P., Rossetto, O.C., Penha, J.M., Santos, S.A., Eds.; Pensoft: Moscow, Russia, 2011 ; pp. $469-496$.

93. Sverlij, S.; Liotta, J.; Minotti, P.G.; Brancolini, F.; Baigún, C.; Firpo Lacoste, F. Los peces del corredor fluvial Paraná-Paraguay. In Sistemas de Paisajes de Humedales del Corredorr Fluvial Paraná-Paraguay; Benzaquen, L., Blanco, D.E., Bo, R., Kandus, P., Lingua, G., Minotti, P., Quintana, R.D., Sverlij, S., Vidal, L., Eds.; Secretaría de Ambiente y Desarrollo Sustentable: Buenos Aires, Argentina; Wetlands International: Wageningen, The Netherlands; UNSAM: Buenos Aires, Argentina, 2013; pp. 341-356.

94. Sverlij, S.; Espinach Ros, A.; Orti, G. Sinópsis de los Datos Biológicos y Pesqueros del Sábalo (Prochilodus lineatus) (Valenciennes 1847); Sinópsis sobre la Pesca, No. 154; FAO: Rome, Italy, 1993.

95. Bonetto, A.A.; Roldan, D.; Canon Veron, M. Algunos aspectos estructurales y ecológicos de la ictiofauna del sistema del Ibera (Corrientes, Arg.). Ecosur 1981, 8, 79-89.

96. Wantzen, K.M.; da Cunha, C.N.; Junk, W.J.; Girard, P.; Rossetto, O.C.; Penha, J.M.; Couto, E.G.; Becker, M.; Priante, G.; Tomas, W.M.; et al. Towards a sustainable man-agement concept for ecosystem services of the Pantanal Wetland. Ecohydrol. Hydrobiol. 2008, 8, 115-138. [CrossRef]

97. Calheiros, D.F.; de Oliveira, M.D.; Padovani, C.R. Hydro-ecological processes and anthropogenic impacts on the ecosystem services of the Pantanal Wetland. In Tropical Wetland Management: The South-American Pantanal and the International Experience; Ioris, A.A.R., Ed.; Ashgate Publishing: Farnham, UK, 2012; pp. 29-57.

98. Girard, P. The Pantaneiros, perceptions and conflicts about the environment in the Pantanal. In Tropical Wetland Management: The South-American Pantanal and International Experience; Ioris, A.A.R., Ed.; Ashgate Publishing: Farnham, UK, 2012 ; pp. 7-27.

99. Junk, W.J.; Silva, C.J. O pulso de unundaçao: Base para o manejo do Pantanal. In Ecossistemas Brasileiros: Manejo e Conservaçao Expressao; Claudino Sales, V., Ed.; Gráfica e Editora: Fortaleza, Brasil, 2003; pp. 179-188.

100. Constanza, R.; d’Arge, R.; de Groot, R.; Farber, S.; Grasso, M.; Hannon, B.; Limburg, K.; Naeem, S.; O’Neill, R.V.; Paruelo, J.; et al. The value of the world's ecosystem services and natural capital. Nature 1997, 15, 253-260. [CrossRef]

101. Seidl, A.F.; Moraes, A.S. Global valuation of ecosystem services: Application to the Pantanal da Nhecolandia, Brazil. Ecol. Econom. 2000, 33, 1-6. [CrossRef]

102. Kandus, P.; Minotti, P. Distribución de terraplenes y áreas endicadas en la región del Delta del Paraná. In Endicamientos y Terraplenes en el Delta del Paraná: Situación, Efectos Ambientales y Marco Jurídico; Blanco, D., Méndez, F., Eds.; Fundación para la Conservación y el Uso Sustentable de los Humedales Wetlands International—LAC: Wageningen, The Netherlands, 2010; pp. 15-32.

103. Minotti, P.; Baigún, C.; Kandus, P.; Quintana, R.; Borro, M.; Schivo, F.; Morandeira, N.; Gramuglia, P.; Brancolini, F. Servicios ecosistémicos en la ecorregión del Delta del Paraná: Consideraciones sobre usos y tendencias y criterios para su conservación. In Estrategias Integradas de Mitigación y Adaptación a Cambios Globales; Fernandez Reyes, L., Volpedo, A., Perez Carrera, A., Eds.; PIUBAC-CYTED: Buenos Aires, Argentina, 2010; pp. 259-272.

104. Oddi, J.D.; Kandus, P. Bienes y servicios de los humedales del Bajo Delta Insular. In El Patrimonio Natural Y Cultural Del Bajo Delta Insular; Bases Para Su Conservación Y Uso Sustentable; Convención Internacional sobre los Humedales (Ramsar, Irán, 1971); Quintana, R., Villar, V., Astrada, E., Saccone, P., Malzof, S., Eds.; Aprendelta: Buenos Aires, Argentina, 2011.

105. Galperín, G.; Fossati, V.; Lottici, M.V. Valoración socio-económica de los bienes y servicios del humedal del Delta del Paraná; Fundación Humedales/Wetlands International: Buenos Aires, Argentina, 2013.

106. Béné, C.; Arthur, R.; Norbury, H.; Allison, E.H.; Beveridge, M.; Bush, S.; Campling, L.; Leschen, W.; Squires, D.; Thilsted, S.; et al. Contribution of fisheries and aquaculture to food security and poverty reduction: Assessing the current evidence. World Develop. 2016, 79, 177-196. [CrossRef]

107. Béné, C.; Macfadyen, G.; Allison, E.H. Increasing the Contribution of Small-Scale Fisheries to Poverty Alleviation and Food Security, Fisheries and Aquaculture Technical Papers 481; Food and Agriculture Organization: Rome, Italy, 2007.

108. Funge-Smith, S.J.; Benett, A. A fresh look at inland fisheries and their role in food security and livelihoods. Fish Fish. 2019, 20, 1176-1195. [CrossRef]

109. Alho, C.J.R.; Reis, R.E. Exposure of fishery resources to environmental and socioeconomic threats within the Pantanal wetland of South America. Int. J. Aquac. Fish. Sci. 2017, 3, 022-029.

110. Chiaravalloti, R.M. Overfihing or over reacting? Mangement of fisheries in the Pantanal wetland, Brazil. Conserv. Soc. 2017, 15, 111-122. [CrossRef]

111. Catella, A.C.; Campos, F.L.; Albuquerque, S.P. Sistema de Controle da Pesca de Mato Grosso Do Sul SCPESCA/MS—22—2015; Boletim de Pesquisa e Desenvolvimento 131; EMBRAPA: Brasilia, Brazil, 2016.

112. Martin-Ortega, J.; Ioris, A.; Glenk, K. Preliminary Exploration of Stake-Holders Perception of the Environmental State and Changes in the Pantanal Wetland. Pantanal International Network. 2011. Available online: http://www.macaulay.ac.uk/ pantanal/Preliminarystakeholder-analysis-report080511.pdf (accessed on 25 January 2021).

113. Baigún, C.; Minotti, P.; Oldani, N. Assessment of sábalo (Prochilodus lineatus) fisheries in the lower Paraná River basin (Argentina) based on hydrological, biological and fishery indicators. Neotrop. Ichthyol. 2013, 11, 191-201. [CrossRef]

114. Carolsfeld, J.; Harvey, B.; Ross, C.; Baer, A. (Eds.) Migratory Fishes of South America: Biology, Fisheries and Conserva-Tion Status; The World Bank: Ottawa, ON, Canada, 2003. 
115. Gottgens, J.F.; Perry, J.E.; Fortney, R.H.; Meyer, J.E.; Benedict, M.; Rood, B.E. The Paraguay-Paraná Hidrovía: Protecting the Pantanal with lessons from the past. BioScience 2011, 51, 301-303. [CrossRef]

116. Gioia, C.J. The great waterways project of South America. Proj. Apprais. 1987, 2, 243-250. [CrossRef]

117. Kanashiro, K. Hidrovia Do Rio Paraguai-EVTEA Estudio de Viabilidad Técnica, Econômica y AmbientalInforma-tivo. Available online: https://issuu.com/ufpritti/docs/informativo_spread_novo_(accessed on 15 April 2021).

118. Richards, P.; Pellegrina, H.; VanWey, L.; Spera, S. Soybean development: The impact of a decade of agricultural change on urban and economic growth in Mato Grosso, Brazil. PLoS ONE 2015, 10, e0122510.

119. Schulz, C.; Martin-Ortega, J.; Glenk, K.; Ioris, A.A.R. The value base of water governance: A multi-disciplinary per-spective. Ecol. Econom. 2017, 131, 241-249. [CrossRef]

120. Internave Engenharia. Hidrovia Paraguai-Paraná; Estudo de viabilidade econômica; Relatório final; Resumo; InternaveEngenharia S.C. Ltd.: San Pablo, Brasil, 1992.

121. Taylor-Golder-Consular-Connal. Evaluación del Impacto Ambiental en el Desarrollo de la Hidrovía Paraguay-Paraná; Comité Intergubernamental de la Hidrovía (CIH): Asunción, Paraguay; United Nations Office for Project Services (UNOPS): Copenhagen, Denmark; Banco Interamericano de Desarrollo (BID): Washington, DC, USA, 1997.

122. UFPR/ITTI (Universidade Federal Do Paraná, UFPR; Instituto Tecnológico De Transportes e Infraestrutura, ITTI). Hidrovia do Rio Paraguai; Estudo de Viabilidade Técnica, Econômica e Ambiental_EVTEA; UFPR/ITTI: Curitiba, Brasil, 2015.

123. HidroService; Berger, L. Estudio de Ingeniería Hidráulica (HS-LB_EIH. Mejoramiento de las Condiciones de Navegación en la Hidrovía Paraguay-Paraná desde el Puerto de Santa Fe a Corumbá-Puerto Quijarro, Señaliza-ción desde el Puerto de Nueva Palmira a Corumbá-Puerto Quijarro") y Estudios de Ingeniería y Factibilidad Eco-nómica de la Hidrovía Paraguay-Paraná desde Puerto Cáceres hasta Nueva Palmira y Señalización desde Puerto Cáceres a Corumbá. 1996. Available online: http: / / documents1.worldbank.org/curated/en/602071468287100745/pdf/690050pt010ESW0Ambientales00PUBLIC0.pdf (accessed on 15 April 2021).

124. Consorcio Integracion Hidroviaria (COINHI). Estudio Institucional Legal, de Ingeniería, Ambiental, y Económico Complementario Para el Desarrollo de las Obras en la Hidrovía Paraguay-Paraná Entre Puerto Quijarro (Canal Tamengo); CSI: Corumbá, Brasil; GRIMAUX: Santa Fe, Brasil; INTERNAVE: Santa Fe, Brasil; JMR: Santa Fe, Brasil; VIA DONAU: Santa Fe, Brasil, 2004.

125. CSI Ingenieros SA. Estudio de Viabilidad del Mejoramiento del Canal Navegable "Pilcomayorío Apa" del río Paraguay a Través del Sistema de Participación Pública-Privada; Informe de Consultoría al Ministerio de Obras Públicas y Comunicaciones (MOPC, República del Paraguay); The World Bank Group—Contrato 7151467; CSI Ingenieros SA: Montevideo, Uruguay, 2009.

126. Bucher, E.H.; Bonetto, A.; Boyle, T.P.; Canevari, P.; Castro, G.; Huszar, P.; Stone, T. Hidrovia: An Initial Environmental Examination of the Paraguay-Parana Waterway; Wetlands for the Americas: Manomet, MA, USA; Buenos Aires, Argentina, 1993.

127. Bucher, E.; Huszar, P. Critical environmental costs of the Paraguay-Paraná waterway project in South America. Ecol. Econom. 1995, 15, 3-9. [CrossRef]

128. CEBRAC; ICV; WWF. Hidrovía Paraguai-Paraná: Quem Paga a Conta? Análise da Viabilidade Económico-Financeira do Projeto Hidrovia Paraguai-Paraná; CEBRAC: Brasilia, Brasil, 1994; 92p.

129. Huszar, P.; Peterman, P.; Leite, A.; Resende, E.; Schnack, E.; Schneider, E.; Francesco, F.; Rast, G.; Schnack, J.; Wasson, J.; et al. Fact or Fiction: A Review of the Hidrovia Paraguay-Paraná Official Studies; World Wildlife Fund: Toronto, ON, Canada, 1999.

130. EDF; CEBRAC. O Projeto de Navegação da Hidrovia Paraguai-Parana; Relatorio de uma análise independente; CEBRAC: Brasilia, Brasil; Washington, DC, USA, 1997; 230p.

131. Resende, E.K.; Tognetti, S. Ecological and economic context of the proposed Paraguay-Paraná Hidrovia and implications for decision-making. In Implementing Sustainable Development: Integrated Assessment and Participatory Decision-Making Processes; Abaza, H., Baranzini, A., Eds.; Edward Elgar Publishing: Cheltenham, UK, 2002; pp. 119-140.

132. Hidrovía Panel of Experts. The Hidrovía Paraguay-Paraná Navigation Project: Report of an Independent Review; Environmental Defense Fund and the Fundaçoã Centro Brasileiro de Referência e Apoio Cultural: Washington, DC, USA; Brasília, Brasil, 1997.

133. Wetlands International. Una Mirada Sobre los Impactos de la Hidrovía en los Humedales del Corredor Fluvial Paraguay-Paraná; Programa Corredor Azul; Fundación Humedales/Wetlands International: Buenos Aires, Argentina, 2019.

134. Tomas, W.M.; Roque, F.O.; Morato, R.; Medici, P.E.; Chiaravallotu, R.M.; Tortato, F.R.; Penha, J.; Izzo, T.; Garcia, L.C.; Lourival, R.F.F.; et al. Sustainability agenda for the Pantanal wetland: Perspectives on a collaborative interface for science, policy, and decision-making. Trop. Conserv. Sci. 2019, 12, 1-30. [CrossRef]

135. Schulz, C.; Martin-Ortega, J.; Ioris, A.A.R.; Glenk, K. Applying a 'value landscapes approach' to conflicts in water governance: The case of the Paraguay-Paraná Waterway. Ecol. Econom. 2017, 138, 47-55. [CrossRef]

136. Harris, M.B.; Tomas, W.; Mourao, G.; da Silva, C.J.; Guimaraes, E.; Sonoda, F.; Fachim, E. Safeguarding the Pantanal wetlands: Threats and conservation initiatives. Conserv. Biol. 2020, 19, 714-720. [CrossRef]

137. Alho, C.J.R.; Lacher, T.E.; Gonçalves, H.C. Environmental degradation in the Pantanal ecosystem. BioScience 1988, $38,164-171$. [CrossRef]

138. Alho, C.J.R. Biodiversity of the Pantanal: Its magnitude, human occupation, environmental threats and challenges for conservation. Braz. J. Biol. 2011, 71, 229-232. [CrossRef]

139. ANA (Agencia Nacional de Aguas). Plano de Recursos Hidricos da RH-Paraguai; Relatorio Final 2018; ANA: Brasilia, Brasil, 2018. 
140. ANEEL (National Electric Energy Agency). 2018. Available online: https:/ /www.aneel.gov.br/aplicacoes/capacidadebrasil/ capacidadebrasil.cfm (accessed on 24 March 2021).

141. Medina-Campos, M.M.; Tritico, H.; Girard, P.; Zeilhofer, P.; Hamilton, S.K.; Fantin-Cruz, I. Predicted impacts of proposed hydroelectric facilities on fish migration routes upstream from the Pantanal wetland (Brazil). River Res. Appl. 2020, 36, 1-13.

142. Souza Filho, E.E. As barragens na bacia do rio Paraguai e a possivel influencia sobre a descarga fluvial e o transporte de sedimentos. Bol. Geogr. 2013, 31, 117-133. [CrossRef]

143. Fantin-Cruz, I.; Oliveira, M.D.; Campos, J.A.; Campos, M.M.; Ribeiro, L.S.; Mingoti, R.; Souza, M.L.; Pedrollo, O.; Hamilton, S.K. Further development of small hydropower facilities will significantly reduce sediment transport to the Pantanal Wetland of Brazil. Front. Environ. Sci. 2020. [CrossRef]

144. Girard, P.; da Silva, C.; Abdo, M. River-groundwater interactions in the Brazilian Pantanal. The case of the Cuiaba River. J. Hydrol. 2003, 283, 57-66. [CrossRef]

145. Zeilhofer, P.; Moura, R.M. Hydrological changes in the northern Pantanal caused by the Manso dam: Impact analy-sis and suggestions for mitigation. Ecol. Eng. 2009, 35, 105-117. [CrossRef]

146. Galdino, S.; Vieira, L.M.; Pellegrin, L.A. Impactos ambientais e socioeconômicos na bacia do Rio Taquari-Pantanal; Embrapa Pantanal: Corumbá, Brasil, 2006.

147. Rausch, G.A. Estado, Desarrollo y Naturaleza: El caso del proyecto Paraná Medio bajo el paradigma hidráulico nacional (Argentina, 1958-1986). Estud. Socioterrit. Rev. Geograf. 2016, 20, 11-25.

148. Agostinho, A.A.; Gomes, L.C.; Suzuki, H.I.; Júlio, H.F., Jr. Migratory Fishes of the Upper Paraná River Basin, Brazil. In Biology, Fisheries and Conservation Status; Carolsfeld, J., Harvey, B., Ross, C., Baer, A., Eds.; World Bank: Washington, DC, USA; World Fisheries Trust: Victoria, BC, Canada; International Development Research Centre: Ottawa, ON, Canada; The International Bank for Reconstruction and Development/The World Bank: Washington, DC, USA, 2003; pp. 19-98.

149. Oldani, N.O.; Oliveros, O. Estudios limnológicos en una sección transversal del tramo medio del río Paraná. XII: Dinámica temporal de peces de importancia económica. Rev. Asoc. Cs. Nat. Litoral 1984, 15, 175-183. [CrossRef]

150. Godinho, A.L.; Kynard, B. Migratory fishes of Brazil: Life history and fish passage needs. River Res. Appl. 2008, $25,702-712$. [CrossRef]

151. Baigún, C.R.M.; Nestler, J.M.; Oldani, N.O.; Goodwin, R.A.; Weber, L.J. Can North American fish passage tools work for South American migratory fishes? Neotrop. Ichthyol. 2007, 5, 109-119. [CrossRef]

152. Oldani, N.O.; Baigún, C.R.; Nestler, J.M.; Goodwin, R.A. Is fish passage technology saving fish resources in the lower La Plata River basin? Neotrop. Ichthyol. 2007, 5, 89-102. [CrossRef]

153. Baigún, C.; Oldani, N.; van Damme, P. Represas hidroeléctricas en América Latina y su impacto sobre la ictiofauna. In Peces de la Amazonía Boliviana: Potencialidades y Amenaza; van Damme, P.A., Carvajal, F., Molina, J., Eds.; INIA: Cochabamba, Bolivia, 2011; pp. 395-415.

154. Pelicice, F.M.; Pompeu, P.; Agostinho, A.A. Large reservoirs as ecological barriers to downstream movements of Neotropical migratory fish. Fish Fish. 2015, 16, 697-715. [CrossRef]

155. Stevaux, J.C.; Martins, D.P.; Meurer, M. Changes in a large regulated tropical river: The Paraná River downstream from the Porto Primavera Dam, Brazil. Geomorphology 2009, 113, 230-238. [CrossRef]

156. Souza Filho, E.E. Evaluation of the Upper Paraná River discharge controlled by reservoirs. Braz. J. Biol. 2009, 69 (Suppl. 2), 707-716. [CrossRef] [PubMed]

157. Puig, A.; Olguin Salinas, H.; Borus, J.A. Recent changes (1973-2014 versus 1903-1972) in the flow regime of the Lower Paraná River and current fluvial pollution warnings in its Delta Biosphere Reserve. Environ Sci. Pollut. Res. 2016, 23, 11471-11492. [CrossRef]

158. Amsler, M.L.; Drago, E.C. A review of of the suspended sediment budget at the confluence of the Parana and the Paraguay rivers. Hydrol. Process. 2009, 23, 3230-3235. [CrossRef]

159. Hamilton, S. Potential effects of a mayor navigation project (Paraguay-Paraná Hidrovía) on inundation in the Pantanal floodplains. Reg. Rivers Res. Manag. 1999, 15, 289-299. [CrossRef]

160. Hamilton, S.K. Hydrological controls of ecological structure and function in the Pantanal wetland (Brazil). In The Ecohydrology of South American Rivers and Wetlands; IAHS Special Publications $\mathrm{N}^{\circ}$ 6; International Association of Hydrological Sciences: Wallingford, UK, 2002.

161. Sylvester, F.; Kalaci, O.; Leung, B.; Lacoursière-Roussel, A.; Choi, F.; Bravo, M.; Therriault, T.; MacIsaac, H. Hull fouling as an invasion vector: Can simple models explain a complex problem? J. Appl. Ecol. 2011, 48, 415-423. [CrossRef]

162. Gollasch, S. The importance of ship hull fouling as a vector of species introductions into the North Sea. Biofouling 2002, 18, 105-121. [CrossRef]

163. Stockstill, R.L.; Berger, R.C. Simulating Barge Drawdown and Current in Channel and Backwater Areas. J. Waterw. Port Coast. Ocean Eng. 2001, 127, 290-298. [CrossRef]

164. Darrigran, G.; Damborenea, C.A. South American bioinvasion case history: Limnoperna fortunei (Dunker, 1857), the golden mussel. Am. Malac. Bull. 1995, 20, 105-112.

165. Darrigran, G.; Pastorino, G. Distribution of the golden mussel Limnoperna fortunei (Dunker, 1857) (Family Mytlidae) after 10 years invading America. J. Conchol. 2004, 3, 95-102. 
166. Ituarte, C.F. Corbicula and Neocorbicula (Bivalvia: Corbiculidae) in the Paraná, Uruguay and Río de La Plata Basins. Nautilus 1994, 107, 129-136.

167. Callil, C.T.; Dreher Mansur, M.C. Corbiculidae in the Pantanal: History of invasion in southeast and central South America and biometrical data. Amazoniana 2002, 17, 153-167.

168. Boltovskoy, D. Distribution and colonization of Limnoperna fortunei: Special traits of an odd mussel. In Limnoperna Fortunei: The Ecology, Distribution and Control of a Swiftly Spreading Invasive Fouling Mussel; Boltovskoy, D., Ed.; Springer: New York, NY, USA, 2015; pp. 301-312.

169. Boltovskoy, D.; Correa, N.; Cataldo, D.; Sylvester, F. Dispersion and ecological impact of the invasive freshwater bivalve Limnoperna fortunei in the Río de la Plata watershed and beyond. Biol. Invasions 2006, 8, 947-963. [CrossRef]

170. Nakano, D.; Strayer, D.L. Biofouling animals in fresh water: Biology, impacts, and ecosystem engineering. Front. Ecol. Environ. 2016, 12, 167-175. [CrossRef]

171. Linares, M.S.; Callisto, M.; Marques, J.C. Invasive bivalves increase benthic communities complexity in neotropical reservoirs. Ecol. Indicat. 2017, 75, 279-285. [CrossRef]

172. Miyahira, I.C.; Pereira, L.S.; dos Santos, L.N. Non-native freshwater molluscs in the Neotropics: What can be learned from Brazilian reservoirs. Aquat. Invasions 2020, 15, 455-472. [CrossRef]

173. Barletta, M.; Cussac, V.E.; Agostinho, A.A.; Baigun, C.; Okada, E.K.; Catella, A.C.; Fontorua, N.; Pompeu, P.S.; Gimenez-Segura, L.; Batista, V.; et al. Fisheries ecology in South American river basins. In Freshwater Fisheries Ecology; Graig, J.F., Ed.; Wiley Blackwell: Oxford, UK, 2016; pp. 311-348.

174. Mateus, L.A.F.; Vaz, M.M.; Catella, A.C. Fishery and fishing resources in the Pantanal. In The Pantanal: Ecology, Biodiversity and Sustainable Management of a Large Neotropical Seasonal Wetland; Junk, W.J., da Silva, C.J., da Cunha, C.N.K., Wantzen, M., Eds.; Pensoft Publishers: Moscow, Russia, 2011; pp. 621-647.

175. Padovani, C.R.; Cruz, M.L.; Padovani, S.L. Desmatamento do Pantanal brasileiro para o ano 2000. In Simpóosio Sobre Recursos Naturais e Sócio-Economicos do Pantanal, Embrapa Pantanal; Empresa Brasileira de Pesquisa Agropecuária; Embrapa-Pantanal: Corumba, Brasil, 2004; pp. 1-7. Available online: https:/ / observatoriopantanal.org/wp (accessed on 25 January 2021).

176. Machado, R.X.; Costa, E.A. O turismo de pesca em Corumbá, na fronteira oeste do Brasil. Rev. Iberoam. Turismo $2018,8,36-48$.

177. Tomas, W.M.; Cáceres, N.C.; Nunes, A.P.; Fischer, E.; Mourōo, G.; Campos, Z. Mammals in the Pantanal wetland, Brazil. In The Pantanal: Ecology, Biodiversity and Sustainable Management of a Large Neotropical Seasonal Wetland; Junk, W.J., da Silva, C.J., da Cunha, C.N., Wantzen, K.M., Eds.; Pensoft Publishers: Moscow, Russia, 2010; pp. 563-595.

178. Roque, F.O.; Ochoa-Quintero, J.; Ribeiro, D.B.; Sugai, L.S.; Costa-Pereira, R.; Lourival, R.; Bino, G. Upland habitat loss as a threat to Pantanal wetlands. Conserv. Biol. 2016, 30, 1131-1134. [CrossRef]

179. Bergier, I. Effects of highland land-use over lowlands of the Brazilian Pantanal. Sci. Total Environ. 2013, 463-464, 1060-1066. [CrossRef]

180. Rossetto, O.C.; Girardi, E.P. Dinâmica agrária e sustentabilidade socioambiental no Pantanal brasileiro. Rev. Nera 2012, 15, 135-161.

181. Sica, Y.V.; Quintana, R.D.; Radeloff, V.C.; Gavier-Pizarro, G.I. Wetland loss due to land use change in the Lower Paraná River Delta, Argentina. Sci. Total Environ. 2016, 568, 967-978. [CrossRef] [PubMed]

182. Minotti, P. Actualización y Profundización del Mapa de Endicamientos y Terraplenes de la Región del Delta del Paraná; Fundación para la Conservación y el Uso Sustentable de los Humedales Wetlands International—LAC: Wageningen, The Netherlands, 2019 ; p. 27.

183. Quintana, R.D. (Ed.) Ganadería y Calidad de Agua en el Delta del Paraná, Desafíos y Recomendaciones; Fundación Humedales/Wetlands International: Buenos Aires, Argentina, 2019.

184. Bó, R.F.; Quintana, R.D.; Groundsalón, P.; Astrada, E.; Bolkovic, M.L.; Lo, G.; Magnano, A.L. Efectos de los cambios en el régimen hidrológico por las actividades humanas sobre la vegetación y la fauna silvestre del Delta del Río Paraná. In Endicamientos y Terraplenes en el Delta del Paraná: Situación, Efectos Ambientales y Marco Jurídico; Blanco, D.E., Mendez, M.M., Eds.; Fundación para la Conservación y el Uso Sustentable de los Humedales: Buenos Aires, Argentina, 2010; pp. 33-63.

185. Quintana, R.D.; Bó, R.F.; Astrada, E.; Reeves, C. Lineamientos Para Una Ganadería Ambientalmente Sustentable en el Delta del Paraná; Fundación Humedales/Wetlands International LAC: Buenos Aires, Argentina, 2014.

186. Zeilhofer, P.; Lima, E.B.; Lima, G.A. Spatial patterns of water quality in the Cuiabá river basin, central Brazil. Environ. Monit. Assess. 2006, 123, 41-62. [CrossRef]

187. Johnson, K.A.; Johnson, D.E. Methane emissions from cattle. J. Anim. Sci. 1995, 73, 2483-2492. [CrossRef]

188. Yusuf, R.O.; Noor, Z.Z.; Abba, A.H.; Hassan, M.A.; Din, M. Greenhouse gas emissions: Quantifying methane emissions from livestock. Am. J. Eng. Appl. Sci. 2012, 5, 1-8.

189. Dunham, J.B.; Young, M.K.; Rieman, B.E. Effects of fire on fish populations: Landscape perspectives on persis-tence of native fishes and nonnative fish invasions. Forest Ecol. Manag. 2003, 178, 183-196. [CrossRef]

190. Brinson, M.; Malvarez, A. Temperate freshwater wetlands: Types, status, and threats. Environ. Conserv. 2002, 29, 115-133. [CrossRef]

191. Salvia, M.M.; Ceballos, D.S.; Grings, F.; Karszenbaum, H.; Kandus, P. Post-fire effects in wetland environments: Landscape assessment of plant coverage and soil recovery in the Parana River Delta marshes, Argentina. Fire Ecol. 2012, 8, 17-37. [CrossRef]

192. Kan, J. La iniciativa para infraestructura regional suramericana: Estudio del eje hidrovía Paraguay-Paraná a partir del proyecto de reconversión del puerto de Santa Fe. Geograficando 2019, 15, e062. [CrossRef]

193. Roldan, D.; Godoy, S. Conflictos territoriales y culturales en la renovación del frente costero. Rosario (Argentina). Rev. Latinoam. Estud. Urbanos Reg. 2020, 46, 95-115. [CrossRef] 
194. Nascimento, F.L.; Catella, A.C.; Moraes, A.S. Distribuicao espacial do tucunare, Cichla sp. (Pisces, cichlidae), peixe amazonico introduzido no Pantanal, Brasil. Bol. Pesq. Desenv. Embrapa Pantanal 2001, 24, 1-15.

195. Ortega, J.C.G. First record of Peacock bass Cichla kelberi Kullander \& Ferreira, 2006 in the Brazilian Pantanal. BioInvasions Rec. 2015, 4, 133-138.

196. Resende, E.K.; Marques, D.K.; Ferreira, K.L. A successful case of biological invasion: The fish Cichla piquiti, an Amazonian species introduced into the Pantanal, Brazil. Braz. J. Biol. 2008, 68, 799-805. [CrossRef] [PubMed]

197. Pelicice, F.M.; Vitule, J.R.S.; Lima, D.P., Jr.; Orsi, M.L.; Agostinho, A.A. Serious new threat to Brazilian freshwater ecosystems: The naturalization of nonnative fish by decree. Conserv. Lett. 2014, 7, 55-60. [CrossRef]

198. Pelicice, F.M.; Azevedo-Santos, V.M.; Vitule, J.R.; Orsi, M.; Lima, D.P., Jr.; Magalhães, A.L.; Pompeu, P.S.; Petrere, M., Jr.; Agostinho, A.A. Neotropical freshwater fishes imperilled by unsustainable policie. Fish Fish. 2017, 18, 1119-1133. [CrossRef]

199. Laabs, V.; Amelung, W.; Pinto, A.; Wantzen, K.; da Silva, C.; Zech, W. Pesticides in surface water, sedi-ment, and rainfall of the Northeastern Pantanal Basin, Brazil. J. Environ. Qual. 2002, 31, 1636-1648. [CrossRef] [PubMed]

200. Nogueira, F.; Silva, E.C.; Junk, W. Mercury from gold minings in the Pantanal of Poconé. Int. J. Environ. Health Res. 1997, 7, $181-191$. [CrossRef]

201. Leady, B.S.; Gottgens, J.F. Mercury accumulation in sediment cores and along food chains in two regions of the Brazilian Pantanal. Wetl. Ecol. Manag. 2001, 9, 349-361. [CrossRef]

202. CIC Plata (Comité Intergubernamental Coordinador de los Países de la Cuenca del Plata). Marco Institucional y Legal Para la Gestión Integrada de los Recursos Hídricos en la Cuenca del Plata. 2016. Available online: https://cicplata.org/es/documentostematicos / (accessed on 25 January 2021).

203. Blettler, M.C.M.; Garello, N.; Ginon, L.; Abrial, E.; Espinola, L.A.; Wantzen, K.M. Massive plastic pollution in a mega-river of a developing country: Sediment deposition and ingestion by fish (Prochilodus lineatus). Environ. Pollut. 2019, 255, 113348. [CrossRef]

204. Blettler, M.C.M.; Ulla, M.A.; Rabuffetti, A.P.; Garello, N. Plastic pollution in freshwater ecosystems: Macro, me-so, and microplastic debris in a floodplain lake. Environ. Monit. Assess. 2017, 189, 581. [CrossRef]

205. Peluso, J.; Aronzon, C.M.; de Molina, M.R.; del Rojas, C.D.E.; Cristos, D.; Pérez Coll, C.S. Integrated analy-sis of the quality of water bodies from the lower Paraná River basin with different productive uses by physico-chemical and biological indicators. Environ. Pollut. 2020, 263, 114434. [CrossRef]

206. Cataldo, D.; Colombo, J.C.; Botovskoy, D.; Bilos, C.; Landoni, P. Environmental toxicity assessment in the Para-naa river Delta (Argentina): Simultaneous evaluation of selected pollutants and mortality rates of Corbicula fluminea (Bivalvia) early juveniles. Environ. Pollut. 2001, 112, 379-389. [CrossRef]

207. CIC (Comité Intergubernamental Coordinador de los Países de la Cuenca del Plata). Programa Marco para la Gestión Sostenible de los Recursos Hídricos de la Cuenca del Plata, en Relación con los Efectos de la Variabilidad y el Cambio Climático $2010-2015$. 2009. Available online: http://www.cicplata.org/?id=marco_docs (accessed on 20 April 2021).

208. SRC (Secretariat of Ramsar Convention). Estrategia de Conservación y Uso Sustentable de los Humedales Fluviales de la Cuenca del Plata. Available online: http://www.ramsar.org/pdf/sc/40/key_sc40_eginits_b15.pdf (accessed on 20 April 2021).

209. TNC (The Nature Conservancy); Fundación Vida Silvestre Argentina (FVSA); Fundación para el Desarrollo Sustentable del Chaco (DeSdel Chaco); Wildife Conservation Society Bolivia (WCS). Evaluación Ecorregional del Gran Chaco Americano/Gran Chaco Americano Ecoregional Assessment; Fundación Vida Silvestre Argentina: Buenos Aires, Argentina, 2005.

210. ZICOSUR (Zona de Integración del Centro Oeste de América del Sur). Orientaciones Estratégicas para Construir un Paisaje Productivo Sostenible en la Región del Río Paraguay. 2020. Available online: http:/ / zicosur.co/ (accessed on 20 April 2021).

211. Ferreira, A. Pantanal Mato-Grossense: Considerações sobre a proteção constitucional para um desenvolvimento econômico sustentável. Interações Campo Grande 2013, 14, 11-20. [CrossRef]

212. Boscarol, N. Áreas protegidas y humedales del Corredor Fluvial Paraná-Paraguay. In Inventario de los Humedales de Argentina; Sistemas de paisajes de humedales del Corredor Fluvial Paraná-Paraguay; Proyecto GEF 4206 PNUD ARG/10/003; Benzaquén, L., Blanco, D.E., Bó, R.F., Kandus, P., Lingua, G.F., Minotti, P., Quintana, R.D., Sverlij, S., Vidal, L., Eds.; Secretaría de Ambiente y Desarrollo Sustentable de la Nación: Buenos Aires, Argentina, 2013; pp. 357-370.

213. CIC Plata (Comité Intergubernamental Coordinador de los Países de la Cuenca del Plata). Tratado de la Cuenca del Plata. 2016. Available online: https:/ / cicplata.org/es/el-tratado-de-la-cuenca-del-plata/ (accessed on 20 April 2021).

214. Pastorino, L.F.; Irigaray, C.T. Análisis del Marco Legal e Institucional del Corredor Fluvial Paraná-Paraguay; Fundación Humedales/Wetlands International: Buenos Aires, Argentina, 2019.

215. Saguier, M.; Gerlak, A.K.; Villar, P.C.; Baigún, C.; Venturini, V.; Lara, A.; dos Santos, M.A. Interdiscipli-nary research networks and science-policy-society interactions in the Uruguay River Basin. Environ. Develop. 2020, 100601. [CrossRef]

216. Barletta, M.; Jaureguizar, A.J.; Baigún, C.; Fontoura, N.F.; Agostinho, A.A.; Almeida-Val, V.; Val, A.; Torres, R.A.; Jimenes, L.F.; Giarrizzo, T.; et al. Fish and aquatic habitat conservation in South America: A continental overview with emphasis on neotropical systems. J. Fish Biol. 2010, 76, 2118-2176. [CrossRef] [PubMed]

217. Auerbach, D.A.; Deisenroth, D.B.; McShane, R.R.; McCluney, K.E.; LeRoy Poff, N. Beyond the concrete: Ac-counting for ecosystem services from free-flowing rivers. Ecosyst. Serv. 2014, 10, 1-5. [CrossRef]

218. Neiff, J.J. Large rivers of South America: Toward the new approach. Verh. Int. Ver. Theor. Ang. Limnol. 1996, 26, 167-180. [CrossRef]

219. Nestler, J.M.; Baigún, C.R.; Oldani, N.O.; Weber, L.J. Contrasting the Middle Paraná and Mississippi Rivers to develop a template for restoring large floodplain river ecosystems. J. River Basin Manag. 2007, 5, 305-319. [CrossRef] 
220. Schlesinger, S. Pantanal por Inteiro, Não pela Metade: Soja, Hidrovia e Outras Ameaças à Integridade do Pantanal, Mato Grosso; Ecosystem Alliance: Amsterdam, The Netherlands, 2014.

221. Calzada, J.; Bergero, P.; Sesé, A.; Ferrer, N.; Poblete, A.; Wade, G.; Zubizarreta, L.; Gaglianese, O. Beneficios Económicos de la Adecuación y Profundización del Canal Navegable Troncal del río Paraná en el Tramo Timbúes (Gran Rosario)—Océano; Dirección de Informaciones y Estudios Económicos-Bolsa de Comercio de Rosario: Rosario, Argentina, 2016.

222. World Bank. Southern cone inland waterways transportation study. In The Paraguay-Paraná Hidrovia: Its Role in the Regional Economy and Impact on Climate Change; Report 54900_LAC; World Bank: Washington, DC, USA, 2010.

223. Berbery, E.H.; Doyle, M.; Barros, V. Regional precipitation trends. In Climate Change in the La Plata Basin; Barros, V., Clark, R.T., da Silva Diaz, P., Eds.; CIMA: Buenos Aires, Argentina, 2006; pp. 61-73.

224. García, N.; Vargas, W. The Temporal Climatic Variability in the Rio De La Plata Basin Displayed by the River Discharges. Clim. Chang. 1998, 38, 359-379. [CrossRef]

225. Genta, J.L.; Perez Iribarne, G.; Mechoso, C. A Recent increasing trend in the streamflow of rivers in southeastern South America. J. Clim. 1998, 11, 2858-2862. [CrossRef]

226. Camilloni, I. Variabilidad y tendencias hidrológicas en la Cuenca del Plata. In El Cambio Climático en el Río de la Plata; Barros, V., Menéndez, A., Nagy, G., Eds.; CIMA: Buenos Aires, Argentina, 2007; pp. 20-31.

227. Lee, S.; Berbery, H.E. Land cover change effects on the climate of the La Plata Basin. J. Hydromet. 2012, 12, 84-102. [CrossRef]

228. Collischonn, W.; Tucci, C.E.M.; Clarke, R.T. Further evidence of changes in the hydrological regime of the River Paraguay: Part of a wider phenomenon of climate change? J. Hydrol. 2001, 245, 218-238. [CrossRef]

229. Tharme, R.E. A global perspective on environmental flow assessment: Emerging trends in the development and application of environmental flow methodologies for rivers. River Res. Appl. 2003, 19, 397-441. [CrossRef]

230. Bovee, K.D. A Guide to Stream Habitat Analysis Using the Instream Flow Incremental Methodology; Instream Flow Information Paper 12; FWS/OBS-82/26; U.S. Fish and Wildlife Service, Office of Biological Services: Falls Church, VI, USA, 1982.

231. Stalnaker, C.; Lamb, B.L.; Henriksen, J.; Bovee, K.; Bartholow, J. The Instream Flow Incremental Methodology: A Primer for IFIM; Biological Report 29; US Department of the Interior, National Biological Service: Washington, DC, USA, 1995.

232. Matthews, J.; Forslund, A.; McClain, M.E.; Tharme, R.E. More than the fish: Environmental flows for good Poli-cy and governance, poverty alleviation and climate adaptation. Aquat. Procedia 2014, 2, 16-23. [CrossRef]

233. Arthington, A.H.; Tharme, R.E.; Brizga, S.O.; Pusey, B.J.; Kennard, M.J. Environmental flow assessment with em-phasis on holistic methodologies. In Proceedings of the Second International Symposium on the Management of Large Rivers for Fisheries, Phnom Penh, Cambodia, 11-14 February 2003; RAP Publication 2004/17. Welcomme, R., Petr, T., Eds.; FAO Regional Office for Asia and the Pacific: Bangkok, Thailand, 2004; Volume II, pp. 37-66.

234. Boelens, R.; Hoogesteger, J.; Swyngedouw, E.; Vos, J.; Wester, P. Hydrosocial territories: A political ecology per-spective. Water Int. 2016, 41, 1-14. [CrossRef]

235. Seemann, M. Inclusive recognition politics and the struggle over hydrosocial territories in two Bolivian high-land communities. Water Int. 2016, 41, 157-172. [CrossRef]

236. Sneddon, C.; Fox, C. Rethinking transboundary waters: A critical hydropolitics of the Mekong basin. Polit. Geogr. 2006, 2, 181-202. [CrossRef]

237. Folke, C.; Hahn, T.; Olsson, P.; Norberg, J. Adaptive governance of social-ecological systems. Ann. Rev. Environ. Res. 2005, 30, 441-473. [CrossRef]

238. Wilson, J. Matching social and ecological systems in complex ocean fisheries. Ecol. Soc. 2006, 11. Available online: http: //www.ecologyandsociety.org/vol11/iss1/art9 (accessed on 15 April 2021). [CrossRef]

239. Poe, M.R.; Norman, K.C.; Levin, P.S. Cultural dimensions of socioecological systems: Key connections and guiding principles for conservation in coastal environments. Conserv. Lett. 2014, 7, 166-175. [CrossRef]

240. Biswas, A.K. Integrated water resources management: A reassessment. Water Int. 2004, 29, 248-256. [CrossRef]

241. Akamani, K.; Wilson, P.I. Toward the adaptive governance of transboundary water resources. Conserv. Lett. 2011, 4, 409-416. [CrossRef]

242. Dillon, J.; Stevenson, R.B.; Wals, A.E. Introduction to the special section: Moving from citizen to civic science to address wicked conservation problems. Conserv. Biol. 2016, 30, 450-455. [CrossRef]

243. Kimura, A.H.; Kinchy, A. Citizen Science: Probing the Virtues and Contexts of Participatory Research. Engag. Sci. Technol. Soc. 2016, 2, 331-361. [CrossRef]

244. Haywood, B.K.; Besley, J.C. Education, outreach, and inclusive engagement: Towards integrated indicators of successful program outcomes in participatory science. Publ. Underst. Sci. 2014, 23, 92-106. [CrossRef] [PubMed]

245. Knight, A.T.; Cowling, R.M.; Campbell, B.M. Planning for implementation: An operational model for conserva-tion planning. Conserv. Biol. 2006, 20, 408-419. [CrossRef]

246. Castillo, T.I.; Baigun, C.R.M. Identification of artisanal fishing territories and associated conflicts in the mid-dle and lower Parana River (Argentina) through participatory mapping. Appl. Geogr. 2020, 125, 102361. [CrossRef]

247. Poole, P. Land-based communities, geomatics, and biodiversity conservation. Cult. Surv. Quart. 1995, 18, 74-76.

248. PIECAS-DP. Plan Integral Estratégico Para la Conservación y Aprovechamiento Sostenible en el Delta de Paraná. Buenos Aires: Secretaría de Ambiente y Desarrollo Sustentable. 2014. Available online: http:/ / cauceecologico.org/wp-content/uploads/2020 /03/PIECAS-DP-2014.pdf (accessed on 7 October 2019). 
249. Mulvany, S. Análisis del Ordenamiento Territorial e Indicadores de Uso, Intensidades y Ocupación del Suelo del Sector de Islas del Delta del Paraná; Technical Report; Fundacion para la Conservación y el Uso Sustentable de los Humedales, Wetlands International LAC: Buenos Aires, Argentina, 2019; Available online: https:/ /lac.wetlands.org/publicacion/publicaciones-corredor-azul/ (accessed on 20 April 2021).

250. Lynam, T.; de Jong, W.; Sheil, D.; Kusumanto, T.; Evans, K. A review of tools for incorporating community knowledge, preferences and values into decision making in natural resources management. Ecol. Soc. 2007, 12, 5-19. [CrossRef]

251. Reed, M.S. Stakeholder participation for environmental management: A literature review. Biol. Conserv. 2008, 141, $2417-2431$. [CrossRef] 